Pontifícia Universidade $C_{\text {atólica }}$

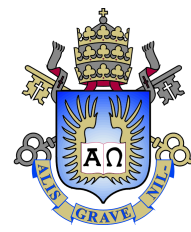

Carlos Henrique Gomes de Brito

\title{
Immigrants' Networks and Trade: Evidence from Brazil
}

Dissertação de Mestrado

Dissertation presented to the Programa de Pós-graduação em Economia da PUC-Rio in partial fulfillment of the requirements for the degree of Mestre em Economia .

Advisor : Prof. Juliano Junqueira Assunção

Co-advisor: Prof. Thierry Andre Louis Verdier 


\section{Carlos Henrique Gomes de Brito}

\section{Immigrants' Networks and Trade: Evidence from Brazil}

Dissertation presented to the Programa de Pós-graduação em Economia da PUC-Rio in partial fulfillment of the requirements for the degree of Mestre em Economia. Approved by the Examination Committee.

Prof. Juliano Junqueira Assunção

Advisor

Departamento de Economia - PUC-Rio

Prof. Thierry Andre Louis Verdier

Co-advisor

Departamento de Economia PUC-Rio - Paris School of

Economics

Prof. Gustavo Gonzaga

Departamento de Economia - PUC-Rio

Prof. Emanuel Ornelas

Fundação Getúlio Vargas - EESP

Rio de Janeiro, April the 8th, 2020 
All rights reserved.

\section{Carlos Henrique Gomes de Brito}

B.A. in Economics, University of Sao Paulo (USP-SP), 2017.

Bibliographic data

Brito, Carlos Henrique Gomes de

Immigrants' Networks and Trade: Evidence from Brazil /

Carlos Henrique Gomes de Brito; advisor: Juliano Junqueira Assunção; co-advisor: Thierry Andre Louis Verdier. - Rio de janeiro: PUC-Rio, Departamento de Economia , 2020.

v., 63 f: il. color. ; $30 \mathrm{~cm}$

Dissertação (mestrado) - Pontifícia Universidade Católica do Rio de Janeiro, Departamento de Economia .

Inclui bibliografia

1. Economia - Teses. 2. Desenvolvimento - Teses. 3. Comércio Internacional;. 4. Imigração;. 5. Cultura.. I. Assunção, Juliano Junqueira. II. Verdier, Thierry Andre Louis. III. Pontifícia Universidade Católica do Rio de Janeiro. Departamento de Economia. IV. Título. 
For my grandparents Laide, Josué (in memoriam) and Antônia, for teaching me what textbooks can't. 


\section{Acknowledgments}

First, I would like to thank my advisors Prof. Juliano Assunção and Prof. Thierry Verdier for guidance and rich contribution to this research. I am also extremely grateful for their support and encouragement during this period.

I wish to thank Prof. Gustavo Gonzaga for granting me access to the RAIS and for his pertinent comments during my presentations.

Financial support from CNPq and PUC-Rio is gratefully acknowledged.

Finally, I am thankful to my family and friends for the support and understanding. 


\section{Abstract}

Brito, Carlos Henrique Gomes de; Assunção, Juliano Junqueira (Advisor); Verdier, Thierry Andre Louis (Co-Advisor). Immigrants' Networks and Trade: Evidence from Brazil. Rio de Janeiro, 2020. 63p. Dissertação de mestrado - Departamento de Economia , Pontifícia Universidade Católica do Rio de Janeiro.

This paper investigates the impact of immigrants' (foreigners) links with their home-country on Brazilian imports and exports of goods. According to the literature, immigrants affect positively both imports and exports because they possess superior knowledge of home country markets aspects, language skills and business contacts that mitigate informal barriers to trade. However, most of the published studies focused on evaluating these matters in developed economies contexts. Differently, to test the empirical significance and magnitude of these effects we use Brazilian detailed data (unexplored by literature) from 2002 to 2016 at the municipality and worker level to estimate augmented gravity equations. According to the results, municipalities with relatively more immigrants from a particular country (especially the ones holding management positions in international trading firms) trade more with this country. The results also indicate larger effects for differentiated (more complex) products and for countries with different religious beliefs and institutions from Brazil.

\section{Keywords}

International Trade; Immigration; Culture. 


\section{Resumo}

Brito, Carlos Henrique Gomes de; Assunção, Juliano Junqueira; Verdier, Thierry Andre Louis. Vínculos de Imigrantes e Comércio Internacional: Evidências do Brasil. Rio de Janeiro, 2020. 63p. Dissertação de Mestrado - Departamento de Economia , Pontifícia Universidade Católica do Rio de Janeiro.

Este artigo investiga o impacto dos vínculos dos imigrantes (estrangeiros) com seu país de origem nas importações e exportações brasileiras. Segundo a literatura, os imigrantes afetam positivamente tanto as importações quanto as exportações porque possuem um conhecimento superior dos aspectos do mercado do seu país de origem, habilidades linguísticas e contatos comerciais que mitigam barreiras informais ao comércio. No entanto, a maioria dos estudos publicados se concentrou em avaliar essas questões em contextos de economias desenvolvidas. Diferentemente, para testar a significância empírica e a magnitude desses efeitos, usamos dados detalhados brasileiros (inexplorados pela literatura) de 2002 a 2016 no nível do município e do trabalhador para estimar equações de gravidade aumentada. De acordo com os resultados, os municípios com relativamente mais imigrantes de um determinado país (especialmente os que ocupam cargos de gerência em empresas que exportam ou importam) comercializam mais com esse país. Os resultados também indicam efeitos maiores para produtos diferenciados (mais complexos) e para países com diferentes crenças religiosas e diferentes instituições do Brasil.

\section{Palavras-chave}

Comércio Internacional; Imigração; Cultura. 


\section{Table of contents}

1 Introduction $\quad 11$

2 Background $\quad 15$

2.1 Immigrants in Brazil $\quad 15$

$\begin{array}{lll}2.2 & \text { Brazilian International Trade } & 17\end{array}$

3 Empirical Strategy $\quad 19$

3.1 Gravity Equation of Trade and Immigration 19

3.2 Poisson Maximum Likelihood Method 22

4 Data $\quad 24$

5 Results $\quad 28$

$\begin{array}{lll}5.1 & \text { Trade Flows } & 28\end{array}$

5.2 Alternative Extensive and Intensive Margins 31

5.3 Differentiated and Homogeneous Goods 34

$\begin{array}{lll}5.4 & \text { Countries' Features } & 36\end{array}$

5.5 Robustness Tests 40

5.5.1 Weighted Immigration Variables 40

5.5.2 Frontier Effect 43

$\begin{array}{lll}6 & \text { Conclusion } & 47\end{array}$

$\begin{array}{ll}\text { A } & 52\end{array}$ 


\section{List of figures}

Figure 2.1 Municipalities share of foreigners workers in $2016 \quad 15$

Figure 2.2 Average state participation in international trade between 2002 and $2016 \quad 18$

Figure 5.1 Paraguayan immigrants' distribution in $2016 \quad 44$

Figure A.1 Uruguayan immigrants' distribution in $2016 \quad 58$

Figure A.2 Argentine immigrants' distribution in 2016

Figure A.3 Bolivian immigrants' distribution in $2016 \quad 60$

Figure A.4 Peruvian immigrants' distribution in 2016

Figure A.5 Colombian immigrants' distribution in $2016 \quad 62$

Figure A.6 Venezuelan immigrants' distribution in 2016 


\section{List of tables}

$\begin{array}{lll}\text { Table 2.1 Share of workers foreign-born } & 17\end{array}$

Table 4.1 Nationalities Available 26

$\begin{array}{lll}\text { Table } 4.2 & \text { Descriptive Statistics } & 27\end{array}$

Table 5.1 Effect of Immigrants on Exports and Imports 30

Table 5.2 Effect of Immigrants on Exports and Imports (Variety of Products)

Table 5.3 Effect of Immigrants on Exports and Imports (Average value per product category) 33

Table 5.4 Effect of Immigrants of Exports and Imports of Differentiated and Non-Diferrentiated Products. 35

Table 5.5 Effect of Immigrants on Exports (Countries' characteristics) 38

Table 5.6 Effect of Immigrants on Imports (Countries' characteristics) 39

Table 5.7 Weights description 41

Table 5.8 Effect of Immigrants on Exports and Imports (Weighted Immigration Variables) 42

Table 5.9 Effect of Immigrants on Exports and Imports (Excluding neighboring countries)

Table A.1 Countries' participation on Brazilian trade flows 52

Table A.2 States' participation on Brazilian trade flows 53

Table A.3 Nationalities Availability in the Data 54

Table A.4 Examples of Product Categories 54

Table A.5 Example of the weighted immigration variables calculation 55

Table A.6 Effect of Immigrants on Exports and Imports (Diminishing Marginal Effects) $\quad 56$

Table A.7 Effect of Immigrants on Exports and Imports (Lags) 57 


\section{Introduction}

International trade incurs in varied types of costs. Tariffs, quotas and transportation are some examples of traditional barriers that buyers and sellers must face when trading internationally. However, some costs (the informal ones) are not formally imposed by formal institutions, regulations, laws or geographic location, they are related to the weak enforcement of international contracts and the high costs of searching for information in foreign markets. For a domestic company it can be costly to obtain complete information about international trading opportunities or about idiosyncrasies of foreign markets. ${ }^{1}$ In an environment with these informal frictions, bilateral trust and access to market information can be determinants to close international trade deals. Accordingly, social and business networks formed by foreigners can enhance trade by increasing bilateral trust and providing information.

First, immigrants potentially bring with them a diverse knowledge about their home economies (quality and availability of products, regulatory peculiarities, way of doing business etc). Moreover, they may have contacts with businessmen and companies from their country. According to Rauch and Trindade (2002), the overseas Chinese communities enhance international business with China by helping match buyers and sellers and also by punishing opportunistic behaviors of community members. Furthermore, immigrants can also inform their compatriots about local consumers' preferences and idiosyncratic domestic market aspects.

Second, besides market information and business connections, immigrants also carry a cultural baggage (habits, beliefs, religion, preferences, etc). These cultural aspects can affect trade by increasing bilateral trust between countries (Europeans possibly trust more other Europeans and individuals with similar cultural values or even with similar physical appearance). According to Guiso et al. (2009), somatic proximity and religious similarity between countries enhance international commerce. Finally, foreigners may have a direct impact on domestic imports since their preferences (that can be diffused among locals) are biased towards their home-country products. ${ }^{2}$

\footnotetext{
${ }^{1}$ Allen (2014), by exploring Philippines agricultural trade data, shows that the difficulty for producers to learn about local spatial price dispersion disturb trade.

${ }^{2}$ Morse and Shive (2011) show that even equity selection in a portfolio can suffer from
} 
Therefore, an Italian immigrant brings contacts with Italian merchants and information about Italian products and regulations. Additionally, he carries specific language skills, identity/patriotism and the taste for Italian goods. Consequently, an immigrant occupying a managing position, for example, can help local firms to identify new trade opportunities and establish/strengthen business relations with his home country. Furthermore, locals can embrace immigrants' preferences, increasing the domestic imports. At the end, these two different types of baggage (culture and information) allow immigrants' networks to foster trade through the reduction of informal costs and the diffusion of their preferences. The scheme below summarizes these ideas.

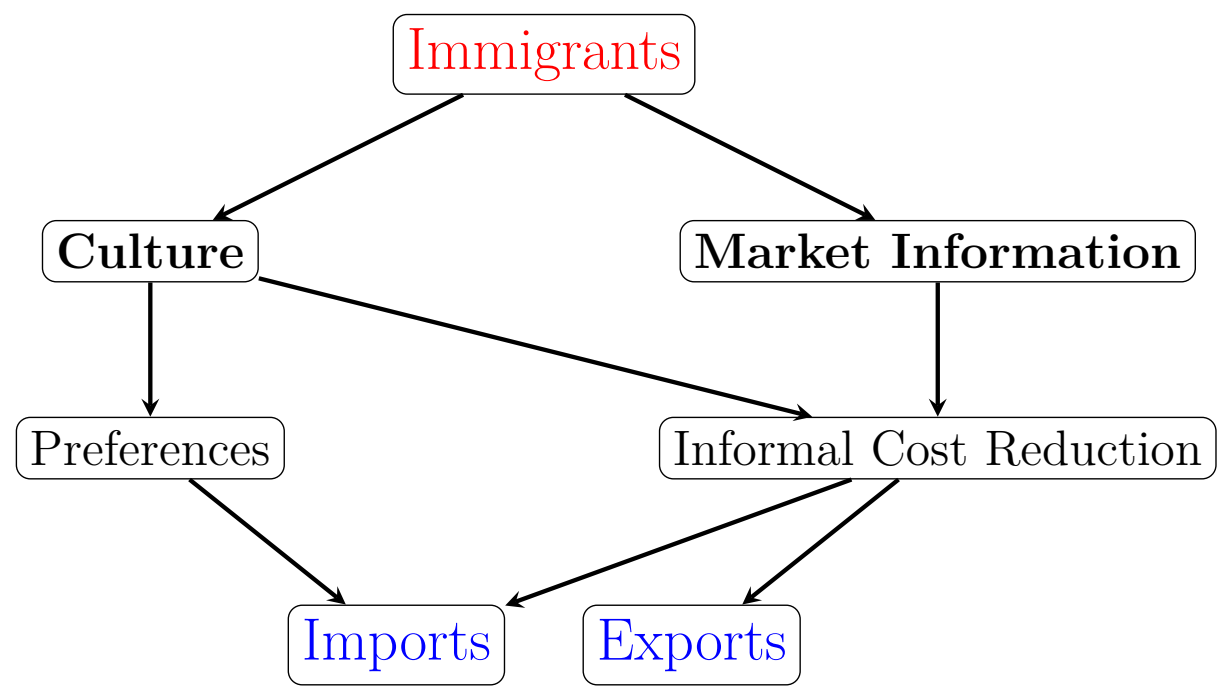

Gould (1994) was the first to study the immigrants' network effect on trade. He estimate augmented gravity equations (an strategy explored by all the other references cited) using US country-level data of bilateral relations with forty seven trading partners. Head and Ries (1998) also explored countrylevel trade data of Canadian trading partners. Both studies find positive effects of immigrants on exports and imports. More recently, new researches have used cross-regional data within a country to exploit the heterogeneous distribution of immigrants across regions: e.g., Combes et al. (2005) (French departments), Peri and Requena-Silvente (2010) (Spanish provinces), Steingress (2015) (US states) and Bandyopadhyay et al. (2008) (US states). Peri and RequenaSilvente (2010), find that, between 1995 and 2008, immigrants increase Spanish provinces' exports through the extensive margin (number of transactions). Bandyopadhyay et al. (2008), by using a panel of exports from US states to 29 countries, also find a positive pro-export effect of ethnic networks for a subset of countries.

home-country (patriotism) bias. 
Aleksynska and Peri (2014), Rauch and Trindade (2002) and Peri and Requena-Silvente (2010) also show that, because negotiations involving more complex (differentiated) goods require more trust between buyers and sellers, immigrants have a larger pro-trade effect for this specific group of goods. Moreover, Peri and Requena-Silvente (2010), Aleksynska and Peri (2014) and Dunlevy (2006) state that immigrants from culturally or institutionally distant countries affect exports and imports the most, because information and trust frictions are larger between countries that possess different cultural and institutional aspects.

The first contribution of this paper is to explore data at the municipality level (that has not been explored by the literature of immigration and trade). Furthermore, we observe immigrants' occupation and whether the employer firm exports or imports, with these information we can measure more precisely the size of immigrants' networks. Aleksynska and Peri (2014) recognize that (in their words): "What has been lacking is an effort to measure more precisely the size of the business network established by immigrants, isolating its specific effects on trade." ${ }^{3}$ We use the share of management positions occupied by immigrants in exporting or importing firms as a proxy for the size of the immigrant's network.

Moreover, the literature has been focused on developed economy environments (such as the United States, Canada, Spain, United Kingdom and France). ${ }^{4}$ Nevertheless, because informal trade costs are quantitatively larger for poor countries (see Anderson and Van Wincoop (2004)) foreigners are thus expected to facilitate bilateral trade mostly in a developing economy context, such as Brazil.

Therefore, our data and the economy environment studied (a developing country) are the distinguishing aspects of our paper and its main contributions. On the other hand, the empirical strategy used follows the same approach explored by the literature: we estimate a standard gravity equation adding immigration variables. We also exploit the heterogeneous effects of differentiated and non-differentiated products and of countries characteristics (cultural and institutional similarity with Brazil). Additionally, we use alternative measures for the extensive and intensive margin unexplored by the literature of immigration and trade.

\footnotetext{
${ }^{3}$ Aleksynska and Peri (2014) also explore occupation but no information whether the employer firm exported or imported is employed, moreover, they use country-level data. The recent paper of Ottaviano et al. (2018) use United Kingdom service trade data at the firm level, but they explore immigrant variables only at the local labor market level and they do not use immigrants occupation.

${ }^{4}$ The paper of Rauch and Trindade (2002), that studies the effect of Chinese immigrants, is an important exception.
} 
According to our results, immigrants indeed carry an specific human capital that can foster Brazilian municipalities' trade with their home countries. Our estimates are robust to different specifications. First, both imports and exports are affected by immigration (extensive and intensive margin). Second, differentiated products, as expected, are more affected than non-differentiated. Additionally, countries culturally distant (in terms of religion beliefs) and with different institutions from Brazil experience larger immigrants' network protrade effect.

The rest of the paper is organized as follows. Section 2 describes immigration and trade environment in Brazil. Section 3 presents the augmented-gravity specification as well as the different estimation strategies used. Section 4 describes the data. Section 5 concentrates the benchmark results, heterogeneous effects and robustness test. Finally, we conclude in Section 6. 


\section{2}

\section{Background}

\section{1}

\section{Immigrants in Brazil}

In 2017, according to the United Nations, only $0.4 \%$ of the Brazilian population was foreign, a very low number even when compared with other South American countries such as Argentina (4.9\%), Chile (2.6\%) and Paraguay (2.4\%). Table 2.1 describes the Brazilian share of workers that are foreignborn per year. Between 2002 and 2016 it almost doubled, reaching $0.30 \%$ in 2016 (for comparison, in the United States, $17.4 \%$ of workers were foreign-born in 2018). Therefore, we expect low average values and a considerable number of zeros for the immigration variables at the Brazilian municipality level explored by this paper.

Figure 2.1: Municipalities share of foreigners workers in 2016

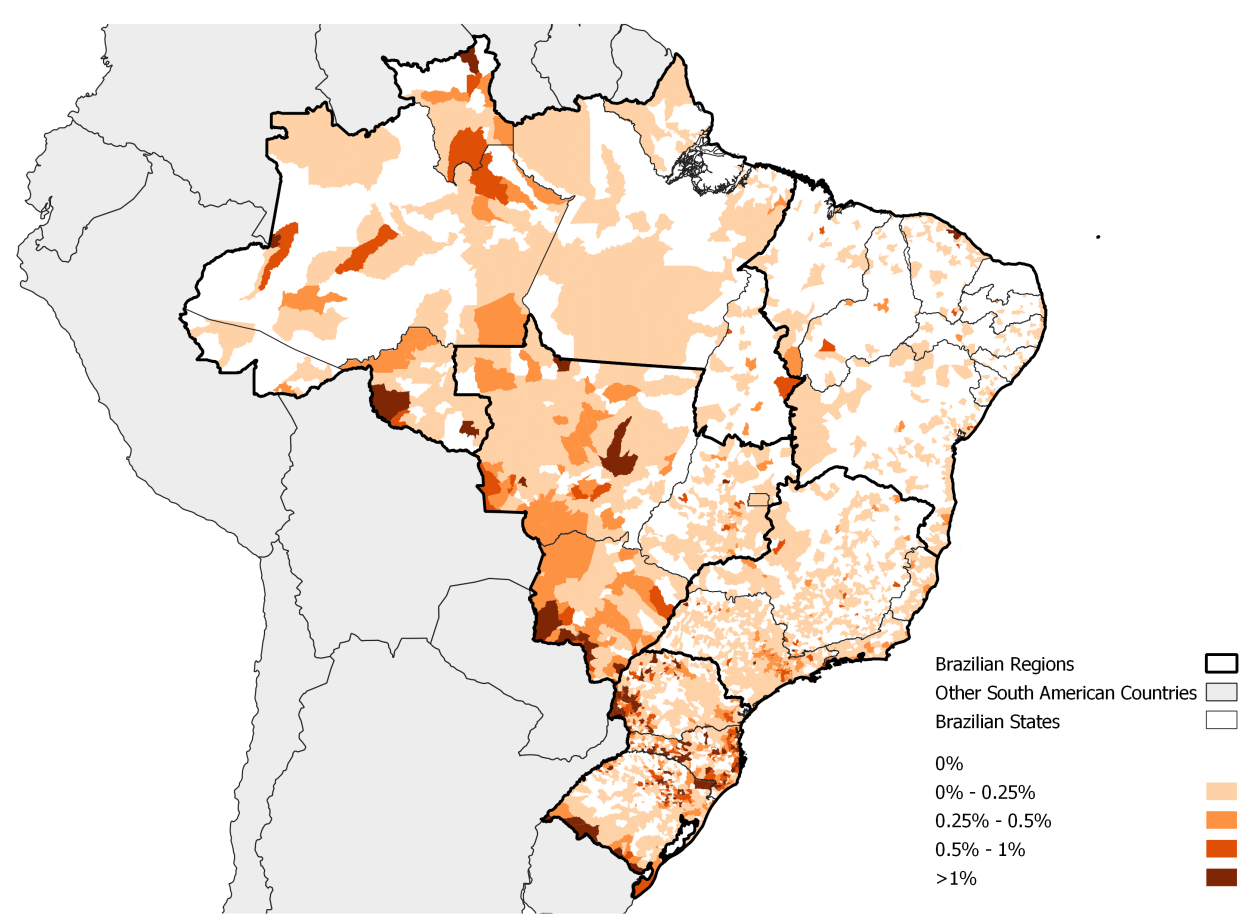

Notes: Only considering foreigners from the 30 countries described in Table 4.1. Furthermore, for the northeast state of Rio Grande do Norte (RN) we do not possess data for 2016 . 
Figure 2.1 shows the share of immigrants in the municipalities' labor market in 2016. We can see high concentrations of immigrants on the borders with other South American countries (specially Uruguay, Argentina, Paraguay and Bolivia) and there are a considerable number of municipalities with less than $0.25 \%$ of foreign-born workers. Except for that, we can't identify any specific geographic pattern.

Brazil's bureaucratic procedures to apply for a residence and work visa can be complex, expensive and lengthy. The work visa application may take two to three months to be processed. The visa fee is 290 dollars for Americans, not including eventual spending with the translation of documents and other bureaucratic procedures. First, to hire a foreigner, a firm must meet some requirements, it must be fully-regulated and its employees must be composed of at least $75 \%$ of Brazilians. Second, the permission to live in Brazil does not come with the permission to work, therefore, a foreigner must attend two different process if he/she wants to work in Brazil. Additionally, to get a work visa, you have to possess a job offer, because the prospective employer starts the procedure by applying for a work visa in your behalf. Once the job offer is approved (execution period varies between 30 and 45 days), you must continue the application process at your home embassy. The work visa is, therefore, restricted to a specific employer firm, so you won't be able to change employers without permission. After arriving in Brazil, you must also apply for other several documents such as the Alien Registration Card, Labor and Social Security Booklet and a tax identification card.

South American countries such as Argentina, Paraguay, Uruguay, Bolivia and Chile together with Portugal and Haiti are the countries that most send immigrants to Brazil (see Table A.4 in the Appendix). Brazil grant advantages and special conditions to Portuguese and citizens from Mercosul countries (Argentina, Paraguay and Uruguay) to work and live in Brazilian territory. Haitian immigration to Brazil increased especially after the earthquake of 2010 that destroyed the Caribbean country. Haiti also suffers from frequent social and political conflicts and is considered the poorest country of the American Continent. 
Table 2.1: Share of workers foreign-born

\begin{tabular}{|c|c|c|c|}
\hline Year & \# Workers & \# Foreign Workers & \% \\
\hline 2002 & $30,272,805$ & 42,895 & 0.14 \\
\hline 2003 & $31,564,982$ & 43,441 & 0.14 \\
\hline 2004 & $37,273,675$ & 52,398 & 0.14 \\
\hline 2005 & $34,946,192$ & 44,247 & 0.13 \\
\hline 2006 & $36,775,098$ & 43,822 & 0.12 \\
\hline 2007 & $38,822,449$ & 47,459 & 0.12 \\
\hline 2008 & $41,162,476$ & 49,870 & 0.12 \\
\hline 2009 & $42,861,707$ & 53,358 & 0.12 \\
\hline 2010 & $45,376,730$ & 57,948 & 0.13 \\
\hline 2011 & $47,406,372$ & 66,924 & 0.14 \\
\hline 2012 & $49,277,702$ & 80,202 & 0.16 \\
\hline 2013 & $50,712,901$ & 101,269 & 0.20 \\
\hline 2014 & $51,829,287$ & 127,908 & 0.25 \\
\hline 2015 & $51,345,125$ & 146,926 & 0.29 \\
\hline 2016 & $49,599,913$ & 149,567 & 0.30 \\
\hline
\end{tabular}

Notes: "\# Workers" = the number of workers. "\# Foreign Workers" = the number of workers that are not Brazilians or naturalized as Brazilians.

\section{2}

\section{Brazilian International Trade}

When compared with developed countries, Brazilian economy is much more closed to international trade. Exports and imports represented together, in 2016, only $24.5 \%$ of Brazilian GDP, much less than the other BRICS countries: Russia (46.3\%), India (40.2\%), China (37.2\%) and South Africa (60.6\%). ${ }^{1}$ Therefore, we should also expect low average values and a considerable number of zeros for the trade flows between Brazilian municipalities and countries.

United States, China and Argentina are the three most important Brazilian trade partners representing together, in 2016, $41 \%$ and $39 \%$ of Brazilian imports and exports, respectively. ${ }^{2}$ Brazil is one of the World's largest commodities exporter (top exports are Soybeans, Iron Ore, Crude Petroleum and Raw Sugar). Brazil's top imports are crude oil, automotives, liquid oils, autoparts and Drugs/Medicine. Finally, Brazil is part of the Mercosul, an

\footnotetext{
${ }^{1}$ Source: World Bank national accounts data and OECD National Accounts data files.

${ }^{2}$ See more details about Brazilian trading partners' participation in exports and imports in Table A.1 in the Appendix.
} 
intergovernmental organization that establishes a customs union and common commercial policy between Brazil, Argentina, Paraguay and Uruguay.

Figure 2.2 shows the distribution of exports and imports across the 26 states and the federal district. The distribution is very uneven, the state of São Paulo is the biggest exporter and importer and the Southeast region concentrates more than half of the exports and imports. ${ }^{3}$

Figure 2.2: Average state participation in international trade between 2002 and 2016

Exports

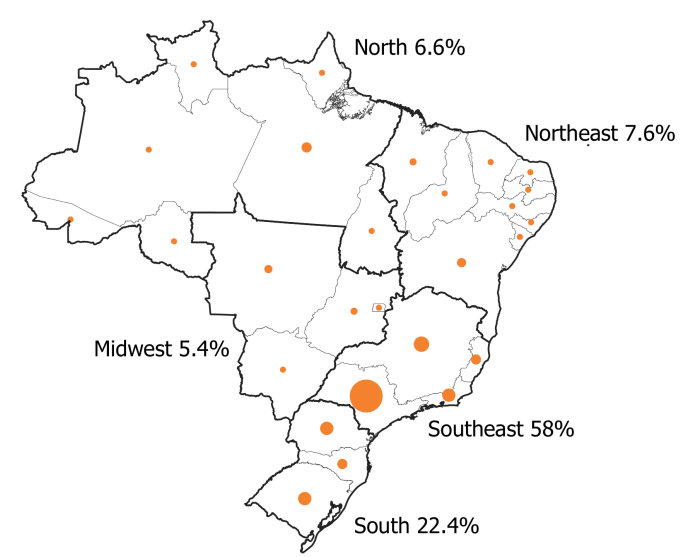

Imports

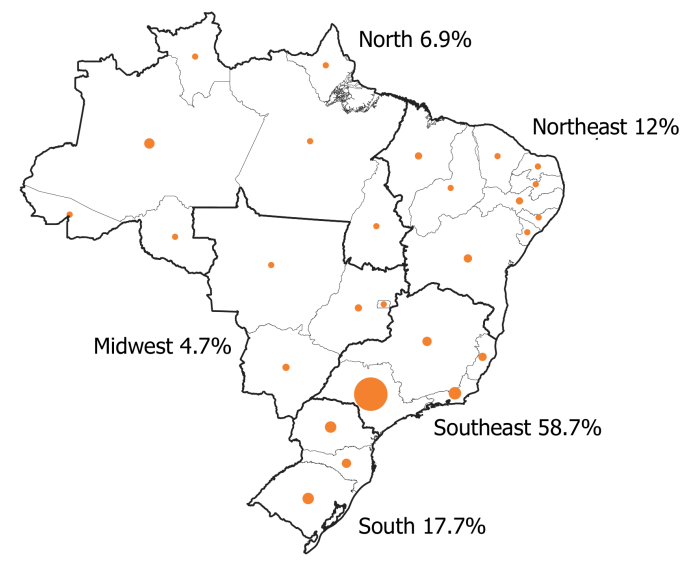

${ }^{3}$ See more details regarding the states' participation in exports and imports in Table A.2 in the Appendix. 


\section{Empirical Strategy}

\section{1}

\section{Gravity Equation of Trade and Immigration}

To recover the impact of immigrants' network on trade we estimate separated augmented-gravity equations for exports and imports (equations 3-1 and 3-2). Bergstrand (1985) present a general equilibrium trade model that works as a microeconomic foundation of the gravity equation. The model consider $\mathrm{N}$ countries (each possess an endowment of labor) that trade with each other nationally differentiated products. Firms maximize profits subject to CET (constant elasticity of transformation) technologies and consumers maximize CES (constant elasticity of substitution) utility functions. Finally, the model consider that tariffs and transportation costs (incorporated in the price) are exogenous. The gravitational equation derived from this model predict that the volume of trade between " $\mathrm{i}$ " and "k" will be directly related to the product of their economic masses (represented by the total amount of wages payed by "i" multiplied by the total amount of wages payed by "k"). On the other hand, trade is inversely related to the distance between " $\mathrm{i}$ " and "k" (that works as a proxy for transportation costs) and the tariffs imposed by each country. Finally, the equation derived is not linear on the parameters, therefore, to test empirically the implications of the model, it is applied the logarithm. ${ }^{1}$

In our case, the gravity equations estimated analyze the trade flows during year "t" between municipality "i" and country "k" and include immigrants' network variables in exponential (the same strategy used by the literature). "GDP $i t \times G D P_{k t}$ ", represent the economic masses and "DISTANCE $E_{i k}$ " is the distance between "i" and "k", the domestic tariffs (established by the federal government and common to all municipalities) and the foreign tariffs are controlled by the fixed effects.

${ }^{1}$ The implications of this procedure are described in Section 3.2. 


$$
\begin{aligned}
& \text { Export }_{i k t}=\alpha_{0}\left(G D P_{i t} \times G D P_{k t}\right)^{\alpha_{1}} \times D I S T A N C E_{i k}^{\alpha_{2}} \\
& \times \exp \left(\alpha_{3} I m m i g r \_ \text {Director_Exp } p_{i k t}+\right. \\
& \alpha_{4} I m m i g r \_N o n D i r e c t o r \_E x p_{i k t}+ \\
& \left.\alpha_{5} \text { Immigr }_{i k t}+\text { fixed effects }\right) \times \mu_{i k t} \\
& \text { Import }_{i k t}=\beta_{0}\left(G D P_{i t} \times G D P_{k t}\right)^{\beta_{1}} \times D I S T A N C E_{i k}^{\beta_{2}} \\
& \times \exp \left(\beta_{3} \text { Immigr_Director_Imp } p_{i k t}+\right. \\
& \beta_{4} \text { Immigr_NonDirector_Imp } p_{i k t}+ \\
& \left.\beta_{5} \text { Immigr }_{i k t}+\text { fixed effects }\right) \times \nu_{i k t}
\end{aligned}
$$

According to the model's implications, we expect: $\alpha_{1}>0, \beta_{1}>0, \alpha_{2}<0$ and $\beta_{2}<0$. Dependent variables "Export $t_{i k t}$ " and "Import $t_{i k t}$ " are, respectively, the total amount exported and the total amount imported by "i" to and from "k" during "t" in dollars. For some specifications we also use, as an outcome, a dummy variables indicating if "i" exported (imported) to (from) "k" during year "t".

We use two different sets of fixed effects. The first set includes year, municipality and countries fixed effects. The second is more demanding. We substitute the year for state-year and the countries for state-country fixed effects. We did not include municipality-country fixed effect because it would be excessively demanding, driving our results artificially to zero. Municipalities have no autonomy to execute trade policies. States, on the other hand, possess some liberty to administrate foreign trade councils, promote international missions to seek new trade partners and execute, for example, incentive programs. ${ }^{2}$ Therefore, a state-country fixed effect also would be more appropriate than municipality-country dummies.

The augmented part of gravity equations 3-1 and 3-2 is composed of three different explanatory immigration variables (see equations 3-3 to 3-7) that represent the participation (share) of immigrants from " $k$ " in different sectors and aspects of the local labor market of municipality "i" during year "t". The first variable, "Immigr Ikt ", is the share of workers in "i" during year

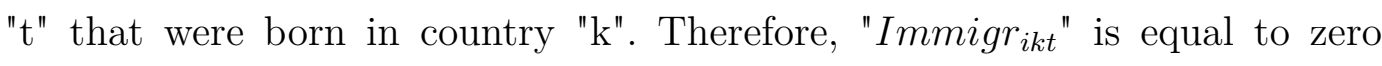
if there is no foreigner from " $\mathrm{k}$ " working in " $\mathrm{i}$ " during " $\mathrm{t}$ " and is equal to one if all workers in " $\mathrm{i}$ " during " $\mathrm{t}$ " have nationality " $\mathrm{k}$ ". Differently, variable "Immigr_Director_Exp ikt ("Immigr_Director_Imp $i k t ")$ represents the

${ }^{2}$ The federal sphere controls the most important trade policy devices, such as the definition of tariffs. 
share of management positions in exporting (importing) firms in "i" during "t" occupied by immigrants from "k". Similarly, "Immigr_NonDirector_Exp $p_{i k t}$ " ("Immigr_NonDirector_Impikt") represents the share of non-management positions in exporting (importing) firms in " $\mathrm{i}$ " during " $\mathrm{t}$ " occupied by immigrants from "k". Therefore, all five immigration variables assume values between zero and one. ${ }^{3}$ The definitions of management and non-management positions and other technical details are described in the data section.

$$
\operatorname{Immigr}_{i k t}=\frac{\# \text { foreigners }_{\text {Kit }}}{\# \text { workers }_{i t}}
$$

$$
\text { Immigr_Director_Exp }_{i k t}=\frac{\text { foreigners }_{K} \text { directors in exporters }_{i t}}{\# \text { workers directors in exporters }_{i t}}
$$

$$
\text { Immigr_Director_Imp }{ }_{i k t}=\frac{\# \text { foreigners }_{K} \text { directors in importers }_{i t}}{\# \text { workers directors in importers }}
$$

$$
\text { Immigr_NonDirector_Exp } \operatorname{Ext}_{i k t}=\frac{\text { foreigners }_{K} \text { non-directors in exporters }_{i t}}{\# \text { workers non-directors in exporters }}
$$

$$
\text { Immigr_NonDirector_Imp }_{i k t}=\frac{\# \text { foreigners }_{K} \text { non-directors in importers }_{i t}}{\# \text { workers non-directors in importers }_{i t}}
$$

Highly educated immigrants can hold and absorb more international information, consequently, they are those that most promote trade (see Felbermayr and Jung (2009) and Aleksynska and Peri (2014)). However, since we have data regarding immigrants' occupation and whether the employer firm exports or imports, we can measure more precisely the size immigrants' network. Foreigners that hold managing positions (mostly highly educated) in firms that trade internationally are the ones most likely to foster exports or imports by bringing their cultural values and information directly to trade negotiations, meetings and business plans. Therefore, Immigr_Director_Exp and Immigr_Director_Imp capture immigrants' network effect (therefore, our parameters of interest are $\alpha_{3}$ and $\beta_{3}$ ). On the other hand, immigrants oc-

${ }^{3}$ Figures A.1 to A.6 in the Appendix present, by South American nationality, the geographic dispersion of all the five immigration measures specified by equations $3-3$ to 3-7. 
cupying only "production" (non-administrative) positions do not have space to use their specific human capital and, consequently, they should not increase trade $\left(\alpha_{4}=0\right.$ and $\left.\beta_{4}=0\right)$.

Two sources of endogeneity could bias our OLS estimates of equations 3-1 and 3-2. First, municipalities that possess better economic performances (and potentially export and import more) will be more attractive to immigrants. Second, a Japanese multinational company with plants in Brazil (that certainly trades with Japan) would probably employ Japaneses. Therefore, trade can create immigration too (a reverse causality problem). However, as pointed out by Aleksynska and Peri (2014), some aspects of our main specification can mitigate this problem. First, while our immigration variables are a stock (we consider immigrants that are working in " $\mathrm{t}$ " but came to Brazil decades ago, for example) trade variables are a flow (represent only the amount transacted during year "t"). Second, variable "Immigr $i k t$ " (that works as a proxy for the share of immigrants from " $k$ " in the local society "i") controls for some of the omitted variables that affect migration and trade, which alleviates the distortion in $\alpha_{3}$ and $\beta_{3}$ (our parameters of interest). The papers that use another strategies to deal with endogeneity (instruments or natural experiments) are exceptions and also find pro-trade effects. Steingress (2015) and Parsons and Vézina (2018) explore how exogenous distribution of immigrants (thanks to historical and natural events and the US refugee resettlement program) affect US states exports and imports. Ottaviano et al. (2018) and Combes et al. (2005) use shift-share instruments. ${ }^{4}$

Genc et al. (2012)

\section{2}

\section{Poisson Maximum Likelihood Method}

Both equations 3-1 and 3-2 are estimated, as usually happens with gravity models, after a "log-linearization" process, however, this procedure causes two problems. First, using the logarithm of trade flows converts zero trade flows into missing values and this may induce selection bias and cause loss of valuable information. Second, if $\mu_{i k t}$ and $\nu_{i k t}$ are heteroskedastic, which is highly probable in practice, the expected value of $\ln \left(\mu_{i k t}\right)$ and $\ln \left(\nu_{i k t}\right)$ depend on explanatory variables values. Consequently, OLS assumptions are violated and the estimated parameters are no longer unbiased and consistent. Although we could overcome the first problem by using the logarithm of trade flows plus

\footnotetext{
${ }^{4}$ Combes et al. (2005) focus on domestic trade between French departments. According to Jaeger et al. (2018), if the distribution of immigrants inflows is stable over time, exclusion restriction of shift-share instruments may not be valid.
} 
one, the second problem would not be solved. Therefore, we need a different estimation strategy.

Silva and Tenreyro (2006) suggest the use of Poisson maximum likelihood. This estimation method allows us to include trade variables in level (consequently, no information would be missed) and it also provides consistent estimates of the original nonlinear model (equations 3-1 and 3-2). Additionally, even though the dependent variable is in level, the interpretation of the parameters is the same as in an OLS with the dependent variable in logarithm. Finally, the Poisson estimator is consistent in the presence of fixed effects. Therefore, we also estimate equations 3-1 and 3-2 using a Pseudo Poisson Maximum Likelihood (PPML). 


\section{Data}

We explore municipality data to identify the impact of immigrants' network on trade. The 5,570 Brazilian municipalities are a well defined portion of the territory with relative administrative autonomy, they are governed by a mayor and a chamber of representatives and can be compared, with some caveats, with the U.S. counties.

Municipality GDP is calculated by the Brazilian Institute of Geography and Statistics (IBGE) and was converted in dollars using a purchasing power parity rate. Countries' GDP and the PPP rate were obtained from the World Bank. The other control variable DISTANCE $E_{i k}$ is the distance (in 1,000 kilometers) between municipality "i" and the capital of country "k".

Because of business confidentiality the department of industry, foreign trade and services of the Ministry of Economy (responsible for Brazilian trade data) does not provide the value and the destination/origin of exports and imports at the firm level. It only discloses this information for municipalities, which is the sum of the international trade flows of all firms with fiscal residency in the municipality. The Ministry of Economy, however, provides a list of firms, plants and subsidiaries that exported or imported (without specifying the trade partner country) during the year "t". In 2016, for example, 25,044 firms, plants and subsidiaries exported and 40,995 imported to/from a country or multiple countries. We can combine this information with the labor contract data described below to establish if an individual is working or not in an exporting or importing firm.

The labor contracts data base explored to obtain the immigration explanatory variables is also organized by the Ministry of Economy, and is called the Annual Report on Social Information (RAIS). This data reports all the formal labor contracts active or signed in Brazil during a year, in other words, all contracts in which the employer is a tax-registered firm. Therefore, this data does not include informal jobs such as, for example, street vendors and other self-employed workers without registration. ${ }^{1}$ The data contains informa-

\footnotetext{
${ }^{1}$ The informal markets in developing countries employ, in general, a substantial amount of workers. In Brazil, informal workers represent on average $40 \%$ of the population working. However, in our case the informal labor market is irrelevant since the international trade flows accounted for are carried out through tax-registered firms.
} 
tion about the worker (such as age, nationality, gender and schooling), the firm (for example, number of employees and sector) and the contract (such as hiring and separation dates, municipality of the workplace, contracted hours and earnings).

With these data we can follow all the labor contracts signed (or active) by a worker during the year "t", consequently, we occasionally have more than one contract per worker. Therefore, we did some procedures to organize the data before calculating the immigration variables. We considered the most lasting contract in "t" for each worker. The duration of the contract is defined as the number of months that the contract had been active in the year "t". So, for example, if a worker started the year "t" (January, 1st) employed and was fired in February and then employed again by another firm (another contract) in April and kept working until September of " $t$ " we will only consider the second contract. ${ }^{2}$ Therefore, we kept one contract for each individual that worked in "t". If a worker possesses two, or more, contracts with the same duration in " $t$ " we choose the contract with the higher wage.

After organizing the contracts we used the occupation code to classify the workers into directors and non-directors. A worker was considered a director if the name/description of his occupation in the Brazilian occupation code (CBO) dictionary had the words "director" or "manager". Consequently, from CFOs to human resources managers were classified as "directors". 3 Our classification of Directors included five subgroups of the CBO: "General Directors", "Directors of Production and Operations", "Directors of Support Areas", "Production and Operation Managers" and "Support Areas Managers". These five subgroups represent 101 different occupations. We chose to use a less restrictive classification rule because, otherwise, it would be challenging and arbitrary to state whether a specific managing occupation was relevant or not in our case. ${ }^{4}$

Finally, with the classification of firms in exporters and/or importers during " $t$ " we calculated the immigration variables described by equations 3-3 to 3-7. It is important to highlight, as previously mentioned, that we do not have information about the country of destination (origin) of the firm's exports (imports). Therefore, a firm is considered exporter (importer) if it exported

\footnotetext{
${ }^{2}$ Even if, for example, the first contract was active since "t-3" we only take into account the second contract.

${ }^{3}$ Aleksynska and Peri (2014) used the major group 1 of the International Standard Classification of Occupations (ISCO) to identify immigrants in occupations as business directors or managers. The only difference between our classification and theirs is that ISCO major group 1 also includes managing positions in political parties, such as legislators.

${ }^{4}$ In CBO the subgroups considered are represented by the numbers: 121, 122, 123, 141 and 142 .
} 
(imported) during the year "t" to (from) any country.

Table 4.1: Nationalities Available

\begin{tabular}{|l|l|l|l|}
\hline Europe: & Africa: & Asia: & America: \\
\hline Germany & Angola & China & Argentina \\
\hline Belgium & Senegal & Japan & Bolivia \\
\hline United Kingdom & Ghana & South Korea & Chile \\
\hline Spain & South Africa & Russia & Paraguay \\
\hline Portugal & & India & Uruguay \\
\hline France & & Pakistan & Venezuela \\
\hline Switzerland & & & Colombia \\
\hline Italy & & & Peru \\
\hline & & & Haiti \\
\hline & & & Ecuador \\
\hline & & & Canada \\
\hline & & & United States \\
\hline
\end{tabular}

Workers' nationalities are only available for 30 countries, the rest of the nationalities are grouped into categories such as: "Other Latin Americans", "Other Asians", "Other Europeans" and "Other Nationalities". Because the trade immigration effect is country-specific we decided to ignore these categories and only use immigrants which we know precisely the country of birth. The number of "missing" in workers' nationality variable is negligible. Furthermore, the concentration (obtained by exploring this variable) of South American immigrants in Brazilian municipalities that border South American countries (see Figure 2.1 in Section 2 and Figures A.1 to A.6 in the Appendix) corroborates the "quality" of the workers' nationality variable.

In 2016, the 30 countries explored (see Table 4.1), represented $69.6 \%$ (183.5 billion dollars) and 78.1\% (137.3 billion dollars) of Brazilian exports and imports, respectively. ${ }^{5}$ In the end, the panel used had approximately 2,000 municipalities (from 26 states and one federal district) paired with 30 nationalities. Each pair was observed between 2002 and $2016 .^{6}$

\footnotetext{
${ }^{5}$ The average participation of these countries in Brazilian exports and imports between 2002 and 2016 are, respectively, $71.7 \%$ and $75.2 \%$. See more details in the Appendix (Tables A.1 and A.2).

${ }^{6}$ Approximately half of Brazilian municipalities were not considered in the estimation because they presented zero values for some of the denominators of equations 3-3 to 37 for all the years used. Furthermore, some nationalities were only available after 2011 or 2014 (see more details in the Appendix (Table A.3). Additionally, we can't guarantee
} 
Table 4.2 presents the descriptive statistics of the trade and immigration variables. Brazilian municipalities export and import on average 4.4 and 4.3 millions dollars to/from country "k", respectively. A first look at the mean values suggests that immigrants are asymmetrically allocated in managing positions in exporting and importing firms. Foreigners' participation in these specific occupations is approximately 15 times higher than their presence in all jobs. As expected, immigration variables assume very low mean values. The average share of workers from " $i$ " that were born in " $k$ " is only $0.005 \%$, for example.

Table 4.2: Descriptive Statistics

\begin{tabular}{lccccc}
\hline Variable & $\mathrm{N}$ & mean & $\mathrm{sd}$ & $\min$ & $\max$ \\
\hline Immigr & 355,952 & 0.00005 & 0.00090 & 0 & 0.16637 \\
Immigr_Director_Exp & 355,952 & 0.00076 & 0.01286 & 0 & 1 \\
Immigr_Director_Imp & 355,952 & 0.00075 & 0.01286 & 0 & 1 \\
Immigr_NonDirector_Exp & 355,952 & 0.00008 & 0.00218 & 0 & 0.48571 \\
Immigr_NonDirector_Imp & 355,952 & 0.00007 & 0.00176 & 0 & 0.33333 \\
\hline Export & 355,952 & 4.37491 & 47.03593 & 0 & $5,957.106$ \\
Import & 355,952 & 4.28477 & 49.68179 & 0 & $5,583.809$ \\
\hline
\end{tabular}

Notes: We consider in this table only municipalities that possess non-missing values for all the five immigration variables. Exports and Imports are reported in millions of dollars. Immigr is the share of workers of "i" that are immigrants from "k" Immigr_Director_Exp is the share of management positions in exporting firms of " $\mathrm{i}$ " occupied by immigrants from "k" and Immigr_NonDirector_Exp is the share of non-management positions in exporting firms of "i" occupied by immigrants from "k". Immigr_Director_Imp is the share of management positions in importing firms of "i" occupied by immigrants from "k" and Immigr_NonDirector_Imp is the share of non-management positions in importing firms of "i" occupied by immigrants from "k".

that municipalities possess managing positions in exporting/importing firms for all the 15 years analyzed. Therefore, our panel data is not balanced. Additionally, occupation code is available for the 167 municipalities of the state of Rio Grande do Norte only after 2010. 


\section{Results}

\section{1}

\section{Trade Flows}

Table 5.1 presents the immigrants' network trade-creating effect estimated for exports and imports. According to the results, both Immigr_Director_Exp and Immigr_Director_Imp are positive and statistically significant at $5 \%$. Immigrants occupying managing positions seem to affect the probability of exporting and importing (first two columns) that captures the extensive margin. Additionally, they also increase the value exported and imported (last three columns) that represents the intensive margin. According to the results, immigrants' network effect is bigger for imports than exports for both the extensive and intensive margin. An increase of 10 percentage points in Immigr_Director_Exp and Immigr_Director_Imp can increase, respectively, the probability of "i" exporting and importing to "k" in $0.048 \%$ (an increase of $13 \%$ in the mean value of "I(Export $>0$ )") and $0.056 \%$ (an increase of $17 \%$ in the mean value of "I(Import $>0)$ ) ). Moreover, it would increase the value exported in $0.43 \%$ and the value imported in $0.63 \%$. Finally, when we include as a regressor the squared values of Immigr_Director_Exp and Immigr_Director_Imp, immigrants' network effect seems to present diminishing marginal effects (see Table A.6 in Appendix).

Furthermore, the parameters that follow Immigr_NonDirector_Exp and Immigr_NonDirector_Imp, as predicted, are not significant, reinforcing our interpretation that Immigr_Director_Exp and Immigr_Director_Imp are indeed capturing immigrants' network effect. Moreover, the GDP masses and the distance, as expected, affect positively and negatively trade, respectively. We also estimated equations 3-1 and 3-2 using lags of the immigration variables (further predetermined) as an alternative way to deal with possible endogeneity (this strategy is also used by Aleksynska and Peri (2014)). The results do not change (see Table A.7 in the Appendix). ${ }^{1}$

\footnotetext{
${ }^{1}$ Additionally, we estimated (not reported) the gravity equations adding the lag of the dependent variable using OLS and System GMM. The results did not change. However, both strategies had problems regarding autocorrelation of the errors. Additionally, the system GMM failed in the Hassan and Sargan tests. Finally, adding municipality and country
} 
For the intensive margin (last three columns) we calculated the Ramsey (or RESET) test proposed by Silva and Tenreyro (2006). It is a t-test to verify if the square of the fitted values is significant when it is added as a regressor. If it is significant at $5 \%$ level it means that trade might be better approximated by non-linear functional forms. Table 5.1 presents the p-value of this test. First, for both exports and imports PPML estimates pass the test and, therefore, seem to be capturing all the non-linearity. On the other hand, the OLS estimates using $\ln ($ Export +1$)$ and $\ln ($ Import +1$)$ do not pass the test, consequently, they potentially suffer from the bias and inconsistency problems described previously.

population or per capita GDP and Mercosul dummies does not change the results (not reported). 
Table 5.1: Effect of Immigrants on Exports and Imports

\begin{tabular}{|c|c|c|c|c|c|}
\hline & OLS & OLS & PPML & PPML & OLS \\
\hline Panel A. & $\mathrm{I}($ Export $>0)$ & $\mathrm{I}($ Export $>0)$ & Export & Export & $\ln ($ Export +1$)$ \\
\hline \multirow[t]{2}{*}{ Immigr_Director_Exp } & $0.494^{* * *}$ & $0.474^{* * *}$ & $4.311^{* * *}$ & $4.33^{* * *}$ & $6.355^{* * *}$ \\
\hline & $(0.088)$ & $(0.086)$ & $(0.701)$ & $(0.64)$ & $(1.186)$ \\
\hline \multirow[t]{2}{*}{ Immigr_NonDirector_Exp } & 0.318 & 0.103 & -4.591 & -7.80 & -4.525 \\
\hline & $(0.381)$ & $(0.365)$ & $(7.994)$ & $(8.72)$ & $(5.594)$ \\
\hline \multirow[t]{2}{*}{ Immigr } & $5.158^{* * *}$ & $5.451^{* * *}$ & $159.328^{* * *}$ & $159.36^{* * *}$ & $103.529^{* * *}$ \\
\hline & $(1.839)$ & $(1.827)$ & $(18.991)$ & $(27.10)$ & $(29.645)$ \\
\hline \multirow[t]{2}{*}{$\ln \left(\mathrm{GDP} \_\right.$Masses $)$} & $0.088^{* * *}$ & $0.093^{* * *}$ & $1.169^{* * *}$ & $1.22^{* * *}$ & $1.532^{* * *}$ \\
\hline & $(0.004)$ & $(0.004)$ & $(0.068)$ & $(0.07)$ & $(0.055)$ \\
\hline \multirow[t]{2}{*}{$\ln ($ DISTANCE) } & $-0.178^{* * *}$ & $-0.066^{* *}$ & $-0.760^{* * *}$ & -0.18 & -0.377 \\
\hline & $(0.006)$ & $(0.028)$ & $(0.188)$ & $(0.73)$ & $(0.375)$ \\
\hline Observations & 473,427 & 473,427 & 468,072 & 465,781 & 473,427 \\
\hline Municipalities & 2,293 & 2,293 & 2,150 & 2,150 & 2,293 \\
\hline R-squared & 0.410 & 0.433 & 0.718 & 0.767 & 0.488 \\
\hline Ramsey Test p-value & & & 0.2282 & 0.1713 & 0.000 \\
\hline $\operatorname{Mean}(\mathrm{Y})$ & 0.383 & 0.383 & $3,413,820$ & $3,430,611$ & \\
\hline Mean(Immigr_Director_Exp) & 0.0007 & 0.0007 & 0.0006 & 0.007 & 0.0007 \\
\hline sd(Immigr_Director_Exp) & 0.0138 & 0.0138 & 0.0135 & 0.0135 & 0.0138 \\
\hline Panel B. & $\mathrm{I}($ Import $>0)$ & $\mathrm{I}($ Import $>0)$ & Import & Import & $\ln ($ Import +1$)$ \\
\hline \multirow[t]{2}{*}{ Immigr_Director_Imp } & $0.609^{* * *}$ & $0.557^{* * *}$ & 2.684 & $6.27^{* * *}$ & $9.002^{* * *}$ \\
\hline & $(0.096)$ & $(0.092)$ & $(3.006)$ & $(1.96)$ & $(1.318)$ \\
\hline \multirow[t]{2}{*}{ Immigr_NonDirector_Imp } & 0.264 & 0.161 & -9.764 & -8.70 & 5.522 \\
\hline & $(0.420)$ & $(0.312)$ & $(18.830)$ & $(10.28)$ & $(5.017)$ \\
\hline \multirow[t]{2}{*}{ Immigr } & $6.617^{* * *}$ & $2.562^{* *}$ & $199.324^{* *}$ & $139.82^{* * *}$ & 38.552 \\
\hline & $(2.309)$ & $(1.154)$ & $(90.943)$ & $(40.79)$ & $(23.965)$ \\
\hline \multirow[t]{2}{*}{$\ln ($ GDP_Masses $)$} & $0.099^{* * *}$ & $0.098^{* * *}$ & $1.083^{* * *}$ & $0.99^{* * *}$ & $1.503^{* * *}$ \\
\hline & $(0.004)$ & $(0.004)$ & $(0.080)$ & $(0.08)$ & $(0.051)$ \\
\hline \multirow[t]{2}{*}{$\ln ($ DISTANCE) } & $-0.159^{* * *}$ & $-0.461 * * *$ & $-1.607 * * *$ & $-4.73^{* * *}$ & $-6.688^{* * *}$ \\
\hline & $(0.007)$ & $(0.028)$ & $(0.582)$ & $(0.59)$ & $(0.399)$ \\
\hline Observations & 440,555 & 440,555 & 437,008 & 430,361 & 440,555 \\
\hline Municipalities & 2,217 & 2,217 & 2,102 & 2,102 & 2,217 \\
\hline R-squared & 0.471 & 0.486 & 0.800 & 0.863 & 0.564 \\
\hline Ramsey Test p-value & & & 0.8187 & 0.0574 & 0.0123 \\
\hline $\operatorname{Mean}(\mathrm{Y})$ & 0.336 & 0.336 & $3,533,900$ & $3,588,481$ & \\
\hline Mean(Immigr_Director_Imp) & 0.0007 & 0.0007 & 0.0007 & 0.0007 & 0.0007 \\
\hline sd(Immigr_Director_Imp) & 0.014 & 0.014 & 0.0139 & 0.014 & 0.014 \\
\hline Year FE & YES & & YES & & \\
\hline Country FE & YES & & YES & & \\
\hline Municipality FE & YES & YES & YES & YES & YES \\
\hline State-Year FE & & YES & & YES & YES \\
\hline State-Country FE & & YES & & YES & YES \\
\hline
\end{tabular}

Notes (Table 5.1): ${ }^{*}=$ Statistically significant at the 10 percent level. ${ }^{* *}=$ Statistically significant at the 5 percent level. ${ }^{* *}=$ Statistically significant at the 1 percent level. Robust standard errors clustered by the pair municipality-country in parentheses. OLS= Ordinary Least Squares. PPML $=$ Pseudo Poisson Maximum Likelihood. The R-squared for equations estimated with PPML is the Pseudo-R-squared. The Ramsey test is calculated accordingly Notes 
(Table 5.1) (continuation): to Silva and Tenreyro (2006). Dependent variables are a dummy indicating if municipality "i" exported to "k" during "t" $(I($ Export $>0))$, the value exported (Export), the logarithm of the value exported plus $1(\ln ($ Export +1$))$, a dummy indicating if municipality "i" imported to "k" during "t" $($ I Import $>0))$, the value imported (Import) and the logarithm of the value imported plus $1(\ln ($ Import +1$))$. Immigr is the share of workers of "i" that are immigrants from "k", Immigr_Director_Exp (Immigr_Director_Imp) is the share of management positions in exporting (importing) firms of "i" occupied by immigrants from "k". Immigr_NonDirector_Exp (Immigr_NonDirector_Imp) is the share of non-management positions in exporting (importing) firms of "i" occupied by immigrants from "k".

\section{2}

\section{Alternative Extensive and Intensive Margins}

The municipality trade data also provide information about the goods traded between "i" and "k" during "t". There are more than 13,000 internationally tradable products listed by the Ministry of Economy, that are classified in 1,268 categories (see some examples of the categories in Table A.4 in the Appendix). With these categories (the only information about products we have for municipalities) we can measure the exports and imports variety. This would allows us to identify the immigrants' network extensive margin effect on exports and imports by exploring an alternative measure to the dummies used in section 5.1. Therefore, we estimated (with OLS) equations 3-1 and 3-2 using as dependent variable the number of categories exported/imported between municipality "i" and country "k" during year "t".

According to the results presented in Table 5.2, both exports and imports variety are positively affected, the effects is larger for imports. An increment of ten percentage points in Immigr_Director_Exp and Immigr_Director_Imp would increase in $0.10 \%$ and $0.24 \%$ the number of categories exported and imported, respectively.

We also estimated equations 3-1 and 3-2 using as dependent variable the average value exported or imported by product category: total value exported (imported) divided by the number of categories exported (imported). It is an alternative way to measure the intensive margin of immigrants' network effect. According to the results presented in Table 5.3, immigrants affect only the average value imported by category. An increment of ten percentage points of Immigr_Director_Imp would increase in $0.21 \%$ the average value imported by category. ${ }^{2}$

\footnotetext{
${ }^{2}$ It is important to notice that we can't estimate equations 3-1 and 3-2 considering as outcome "ln(1+Average Export by Category)" or "ln(1+Average Import by Category)" because "Average Export by Category" and "Average Import by Category" are missing for municipalities " $\mathrm{i}$ " that do not trade any category of product with "k" during "t".
} 
Table 5.2: Effect of Immigrants on Exports and Imports (Variety of Products)

\begin{tabular}{|c|c|c|c|c|c|}
\hline \multirow[b]{2}{*}{ Panel A. } & \multicolumn{5}{|c|}{$Y=\#$ Products Variety Exported } \\
\hline & $\mathrm{Y}$ & $\mathrm{Y}$ & $\ln (\mathrm{Y})$ & $\ln (1+\mathrm{Y})$ & $\ln (1+Y)$ \\
\hline \multirow[t]{2}{*}{ Immigr_Director_Exp } & $9.436^{* *}$ & $9.781^{* * *}$ & $1.134^{* * *}$ & $1.005^{* * *}$ & $0.987^{* * *}$ \\
\hline & $(3.677)$ & $(3.621)$ & $(0.240)$ & $(0.179)$ & $(0.173)$ \\
\hline \multirow[t]{2}{*}{ Immigr_NonDirector_Exp } & $-147.394^{*}$ & $-151.988^{*}$ & $-4.332^{* *}$ & -1.741 & $-2.396^{*}$ \\
\hline & $(80.509)$ & $(77.729)$ & $(1.741)$ & $(1.257)$ & $(1.322)$ \\
\hline \multirow[t]{2}{*}{ Immigr } & $1,368.294^{* * *}$ & $1,381.194^{* * *}$ & $39.562^{* * *}$ & $31.903^{* * *}$ & $35.037^{* * *}$ \\
\hline & $(479.752)$ & $(453.918)$ & $(8.364)$ & $(6.663)$ & $(6.956)$ \\
\hline \multirow[t]{2}{*}{$\ln \left(\mathrm{GDP} \_\right.$Masses $)$} & $1.170^{* * *}$ & $1.314^{* * *}$ & $0.263^{* * *}$ & $0.155^{* * *}$ & $0.169^{* * *}$ \\
\hline & $(0.075)$ & $(0.077)$ & $(0.013)$ & $(0.006)$ & $(0.006)$ \\
\hline \multirow[t]{2}{*}{$\ln (\mathrm{DISTANCE})$} & $-5.060 * * *$ & -0.740 & -0.179 & $-0.417^{* * *}$ & $0.127^{*}$ \\
\hline & $(0.568)$ & $(4.457)$ & $(0.139)$ & $(0.014)$ & $(0.074)$ \\
\hline Observations & 473,427 & 473,427 & 180,972 & 473,427 & 473,427 \\
\hline Municipalities & 2,293 & 2,293 & 2,015 & 2,293 & 2,293 \\
\hline R-squared & 0.560 & 0.576 & 0.697 & 0.653 & 0.676 \\
\hline $\operatorname{Mean}(\mathrm{Y})$ & 3.415 & 3.415 & & & \\
\hline Mean(Immigr_Director_Exp) & 0.0007 & 0.0007 & 0.0012 & 0.0007 & 0.0007 \\
\hline \multirow[t]{2}{*}{ sd(Immigr_Director_Exp) } & 0.0138 & 0.138 & 0.0166 & 0.138 & 0.138 \\
\hline & \multicolumn{5}{|c|}{$\mathrm{Y}=\#$ Products Variety Imported } \\
\hline Panel B. & Y & $\mathrm{Y}$ & $\ln (\mathrm{Y})$ & $\ln (1+\mathrm{Y})$ & $\ln (1+\mathrm{Y})$ \\
\hline \multirow[t]{2}{*}{ Immigr_Director_Imp } & $51.224^{* * *}$ & $46.852^{* * *}$ & $3.569^{* * *}$ & $2.559^{* * *}$ & $2.380^{* * *}$ \\
\hline & $(7.585)$ & $(7.365)$ & $(0.469)$ & $(0.331)$ & $(0.314)$ \\
\hline \multirow[t]{2}{*}{ Immigr_NonDirector_Imp } & $29.434^{*}$ & 18.901 & 4.603 & 1.677 & 1.338 \\
\hline & $(17.642)$ & $(16.028)$ & $(2.838)$ & $(1.098)$ & $(0.839)$ \\
\hline \multirow[t]{2}{*}{ Immigr } & $149.547^{*}$ & 18.129 & 0.242 & $16.101^{* *}$ & 6.153 \\
\hline & $(85.225)$ & $(57.632)$ & $(3.748)$ & $(6.596)$ & $(4.023)$ \\
\hline \multirow[t]{2}{*}{$\ln \left(\mathrm{GDP} \_\right.$Masses $)$} & $5.873^{* * *}$ & $6.012^{* * *}$ & $0.491^{* * *}$ & $0.315^{* * *}$ & $0.316^{* * *}$ \\
\hline & $(0.295)$ & $(0.314)$ & $(0.020)$ & $(0.010)$ & $(0.010)$ \\
\hline \multirow[t]{2}{*}{$\ln (\mathrm{DISTANCE})$} & $-1.277^{* * *}$ & $-16.556^{* * *}$ & $-2.159^{* * *}$ & $-0.264^{* * *}$ & $-1.238^{* * *}$ \\
\hline & $(0.295)$ & $(1.398)$ & $(0.135)$ & $(0.014)$ & $(0.061)$ \\
\hline Observations & 440,555 & 440,555 & 147,676 & 440,555 & 440,555 \\
\hline Municipalities & 2,217 & 2,217 & 1,893 & 2,217 & 2,217 \\
\hline R-squared & 0.483 & 0.512 & 0.686 & 0.637 & 0.659 \\
\hline $\operatorname{Mean}(\mathrm{Y})$ & 6.772 & 6.772 & & & \\
\hline Mean(Immigr_Director_Imp) & 0.0007 & 0.0007 & 0.0015 & 0.0007 & 0.0007 \\
\hline sd(Immigr_Director_Imp) & 0.014 & 0.014 & 0.017 & 0.014 & 0.014 \\
\hline Year FE & YES & & & YES & \\
\hline Country FE & YES & & & YES & \\
\hline Municipality FE & YES & YES & YES & YES & YES \\
\hline State-Year FE & & YES & YES & & YES \\
\hline State-Country FE & & YES & YES & & YES \\
\hline
\end{tabular}

Notes (Table 5.2): ${ }^{*}=$ Statistically significant at the 10 percent level. ${ }^{* *}=$ Statistically significant at the 5 percent level. ${ }^{* * *}=$ Statistically significant at the 1 percent level. All equations were estimated using OLS. Robust standard errors are clustered by the pair municipality-country in parentheses. Products Variety is the number of types of products exported or imported between "i" and "k". Immigr is the share of workers of "i" that are immigrants from "k", Immigr_Director_Exp(Immigr_Director_Imp) is the share of management positions in exporting (importing) firms of "i" occupied 
Notes (Table 5.2) (continuation): by immigrants from "k". Immigr_NonDirector_Exp (Immigr_NonDirector_Imp) is the share of non-management positions in exporting (importing) firms of "i" occupied by immigrants from "k".

Table 5.3: Effect of Immigrants on Exports and Imports (Average value per product category)

$$
\begin{array}{cc}
\mathrm{Y}=\text { Average Export } & \mathrm{Y}=\text { Average Import } \\
\text { by Category } & \text { by Category }
\end{array}
$$

\begin{tabular}{lcc} 
Variables & $\ln (\mathrm{Y})$ & $\ln (\mathrm{Y})$ \\
\hline Immigr_Director_Exp & 0.418 & 0.306 \\
& $(0.482)$ & $(0.484)$ \\
Immigr_NonDirector_Exp & -3.499 & $-4.851^{* *}$ \\
& $(2.442)$ & $(2.458)$
\end{tabular}

Immigr_Director_Imp $2.250^{* * *} \quad 2.062^{* * *}$

Immigr_NonDirector_Imp

$9.061 \quad 5.944$

Immigr

$14.200^{* *} \quad 18.290^{* * *} \quad 16.796^{* *}$

$\ln ($ GDP_Masses $)$

$(6.945)$

(8.360)

$\ln ($ GDP_Masses $)$

$0.678^{* * *}$

$0.678^{* * *}$

$0.388^{* * *}$

$\ln ($ DISTANCE)

(0.053)

0.322

$-0.362^{* * *}$

$-1.938^{* * *}$

Observations

180,977

(0.201)

(0.061)

Municipalities

2,015

180,961

147,692
147,664

R-squared

0.392

2,015

1,893

1,893

Year FE

YES

0.419

0.318

0.349

Country FE

Municipality FE

State-Year FE

State-Country FE
YES

YES

\section{YES}

YES

YES YES

YES

YES
YES

YES

YES

Notes (Table 5.3): ${ }^{*}=$ Statistically significant at the 10 percent level. ${ }^{* *}=$ Statistically significant at the 5 percent level. ${ }^{* * *}=$ Statistically significant at the 1 percent level. All equations were estimated using OLS. Robust standard errors are clustered by the pair municipality-country in parentheses. "Average Export by Category" ("Average Import by Category") is the total value exported (imported) divided by the number of product categories exported (imported). Immigr is the share of workers of " $\mathrm{i}$ " that are immigrants from "k", Immigr_Director_Exp (Immigr_Director_Imp) is the share of management positions in exporting (importing) firms of "i" occupied by immigrants from "k". Immigr_NonDirector_Exp(Immigr_NonDirector_Imp) is the share of non 
Notes(Table 5.3) (continuation): management positions in exporting (importing) firms of "i" occupied by immigrants from "k".

\section{3}

\section{Differentiated and Homogeneous Goods}

To assess heterogeneous immigrants' network effect between differentiated and homogeneous goods we exploited a product classification originally created by Rauch (1999) that is commonly used by the literature of immigration and trade. ${ }^{3}$ Rauch's classification allocates the products into three groups: differentiated (clothes and shoes, for example), referenced priced (such as chemical products) and organized exchanged products (such as coffee). The last two categories have prices quoted without mentioning a brand name or other producer identification.

Because negotiations involving more complex (differentiated) goods are more flexible to debate over price and also require more trust between buyers and sellers, immigrants have more space to enhance the trade of this specific class of goods by reducing informal costs. Therefore, exports and imports of differentiated goods should present a higher $\alpha_{3}$ and $\beta_{3}$, respectively.

Indeed, the results presented in Table 5.4 indicate that Immigr_Director_Exp and Immigr_Director_Imp assume higher values for differentiated products. This strengthens our interpretation that these variables capture immigrants' network trade effect. However, for the extensive margin specifications, we can't reject the hypothesis that $\alpha_{3}\left(\beta_{3}\right)$ for differentiated goods is equal to the $\alpha_{3}\left(\beta_{3}\right)$ for referenced priced goods. ${ }^{4}$

${ }^{3}$ See Aleksynska and Peri (2014), Rauch and Trindade (2002) and Peri and RequenaSilvente (2010).

${ }^{4}$ All specifications with dummies as an outcome were estimated with the same sample. Therefore, in order to test for the differences in the parameter of interest across the types of products, we calculated a simple t-test. The "Z-score" reported in Table 5.4 is the ratio of the difference between $\hat{\alpha}_{3}$ dif $\left(\hat{\beta}_{3}\right.$ dif) and the $\hat{\alpha}_{3}\left(\hat{\beta}_{3}\right.$ dif) of the other product group to the square root of the sum of squared standard errors reported for those coefficients. We only reject the hypothesis that the parameters are equal if the "Z-score" is greater than 1.96. The test is calculated under the assumption that the covariances of coefficient estimates across equations are zero. 
Table 5.4: Effect of Immigrants of Exports and Imports of Differentiated and Non-Diferrentiated Products.

\begin{tabular}{|c|c|c|c|c|c|c|}
\hline & OLS & OLS & OLS & PPML & PPML & PPML \\
\hline Panel A. & I $($ Exp_dif $>0)$ & $\mathrm{I}\left(\mathrm{Exp} \_r e f>0\right)$ & I(Exp_org $>0)$ & Exp_dif & Exp_ref & Exp_org \\
\hline \multirow[t]{2}{*}{ Immigr_Director_Exp } & $0.384^{* * *}$ & $0.338^{* * *}$ & $0.113^{* * *}$ & $4.718^{* * *}$ & $3.643^{* * *}$ & $4.080^{* * *}$ \\
\hline & $(0.081)$ & $(0.073)$ & $(0.041)$ & $(1.323)$ & $(0.823)$ & $(1.064)$ \\
\hline \multirow[t]{2}{*}{ Immigr_NonDirector_Exp } & -0.152 & -0.528 & -0.326 & $-46.446^{* * *}$ & $-41.546^{*}$ & 3.734 \\
\hline & $(0.321)$ & $(0.339)$ & $(0.290)$ & $(16.153)$ & $(24.108)$ & $(6.622)$ \\
\hline \multirow[t]{2}{*}{ Immigr } & $5.099^{* * *}$ & $8.114^{* * *}$ & $7.118^{* * *}$ & $169.709^{* *}$ & $167.064^{* * *}$ & $217.408^{* * *}$ \\
\hline & $(1.426)$ & $(1.831)$ & $(1.247)$ & $(66.947)$ & $(34.780)$ & $(58.134)$ \\
\hline \multirow[t]{2}{*}{$\ln \left(\mathrm{GDP} \_\right.$Masses $)$} & $0.057^{* * *}$ & $0.069^{* * *}$ & $0.039 * * *$ & $0.759^{* * *}$ & $1.326^{* * *}$ & $1.321^{* * *}$ \\
\hline & $(0.004)$ & $(0.004)$ & $(0.003)$ & $(0.104)$ & $(0.094)$ & $(0.144)$ \\
\hline \multirow[t]{2}{*}{$\ln$ (DISTANCE) } & $-0.110^{* * *}$ & $0.063^{* *}$ & 0.032 & $-3.208^{* * *}$ & 0.794 & $2.033^{* *}$ \\
\hline & $(0.025)$ & $(0.025)$ & $(0.020)$ & $(0.669)$ & $(0.831)$ & $(1.016)$ \\
\hline Observations & 473,427 & 473,427 & 473,427 & 412,694 & 408,112 & 325,253 \\
\hline Municipalities & 2,293 & 2,293 & 2,293 & 1,741 & 1,674 & 1,244 \\
\hline R-squared & 0.495 & 0.400 & 0.307 & 0.8352 & 0.7538 & 0.8211 \\
\hline Z-score: $\hat{\gamma}_{2}$ dif $-\hat{\gamma}_{2}$ & & 0.43 & 2.99 & & & \\
\hline Panel B. & I $($ Imp_dif $>0)$ & I $($ Imp_ref $>0)$ & I $($ Imp_org $>0)$ & Imp_dif & Imp_ref & Imp_org \\
\hline \multirow[t]{2}{*}{ Immigr_Director_Imp } & $0.605^{* * *}$ & $0.583^{* * *}$ & $0.277^{* * *}$ & $6.721^{* * *}$ & $6.256^{* * *}$ & -0.884 \\
\hline & $(0.083)$ & $(0.098)$ & $(0.054)$ & $(2.207)$ & $(1.678)$ & $(2.904)$ \\
\hline \multirow[t]{2}{*}{ Immigr_NonDirector_Imp } & 0.068 & -0.125 & $0.866^{* *}$ & 7.414 & 4.986 & -10.734 \\
\hline & $(0.277)$ & $(0.287)$ & $(0.336)$ & $(19.118)$ & $(5.431)$ & $(41.028)$ \\
\hline \multirow[t]{2}{*}{ Immigr } & $3.604^{* * *}$ & $4.206^{* * *}$ & 0.348 & $352.222^{* * *}$ & 17.856 & -13.684 \\
\hline & $(1.004)$ & $(1.241)$ & $(2.131)$ & $(78.454)$ & $(18.401)$ & $(35.139)$ \\
\hline \multirow[t]{2}{*}{$\ln \left(\mathrm{GDP} \_\right.$Masses $)$} & $0.100^{* * *}$ & $0.071^{* * *}$ & $0.024^{* * *}$ & $1.143^{* * *}$ & $0.723^{* * *}$ & $0.396^{*}$ \\
\hline & $(0.004)$ & $(0.004)$ & $(0.002)$ & $(0.088)$ & $(0.093)$ & $(0.228)$ \\
\hline \multirow[t]{2}{*}{$\ln ($ DISTANCE) } & $-0.338 * * *$ & $-0.332^{* * *}$ & $-0.283^{* * *}$ & $-3.715^{* * *}$ & $-1.683^{* *}$ & $-8.088^{* * *}$ \\
\hline & $(0.025)$ & $(0.024)$ & $(0.025)$ & $(0.886)$ & $(0.691)$ & $(1.149)$ \\
\hline Observations & 440,555 & 440,555 & 440,555 & 418,303 & 378,975 & 274,218 \\
\hline Municipalities & 2,217 & 2,217 & 2,217 & 2,006 & 1,604 & 1,056 \\
\hline R-squared & 0.485 & 0.444 & 0.297 & 0.8784 & 0.8096 & 0.8393 \\
\hline Z-score: $\hat{\gamma}_{2}$ dif $-\hat{\gamma}_{2}$ & & 0.18 & 3,38 & & & \\
\hline Municipality FE & YES & YES & YES & YES & YES & YES \\
\hline State-Year FE & YES & YES & YES & YES & YES & YES \\
\hline State-Country FE & YES & YES & YES & YES & YES & YES \\
\hline
\end{tabular}

Notes (Table 5.4) ${ }^{*}=$ Statistically significant at the 10 percent level. ${ }^{* *}=$ Statistically significant at the 5 percent level. ${ }^{* *}=$ Statistically significant at the 1 percent level. Robust standard errors are clustered by the pair municipality-country in parentheses. OLS=Ordinary Least Squares. PPML=Pseudo Poisson Maximum Likelihood. The R-squared for equations estimated with PPML is the Pseudo-R-squared. Exp_dif = exports of differentiated products; Exp_ref $=$ exports of reference priced products; $\mathbf{E x p \_ o r g}=$ exports of organized exchange products. $\mathrm{I}()$ is an indicator function. Immigr is the share of workers of " $\mathrm{i}$ " that are immigrants from "k", Immigr_Director_Exp (Immigr_Director_Imp) is the share of management positions in exporting (importing) firms of "i" occupied by immigrants from "k". Immigr_NonDirector_Exp(Immigr_NonDirector_Imp) is the share of nonmanagement positions in exporting (importing) firms of "i" occupied by immigrants from "k". 


\section{4 \\ Countries' Features}

Aleksynska and Peri (2014) and Ottaviano et al. (2018) verified how countries similarities can affect the bilateral pro-trade effect of immigrants' network. Countries with different market and cultural aspects are the ones that immigrants can affect the most trade. Ottaviano et al. (2018) showed that Non-Anglo-Saxon countries' market are the ones that benefit the most with the pro-exports effect of their immigrants living in United Kingdom. Moreover, Aleksynska and Peri (2014) showed that common language, colonial past and common legal origin reduce immigrants' network effect. To test whether countries features affect foreigners pro-trade effect we interact the immigrants' network variables ("Immigr_Director_Exp" and "Immigr_Director_Imp") with four variables at a time. We use two variables to describe cultural aspects (religion and language) and two other variables to describe institutional aspects (legal origin and "rule of law") of country "k".

The first cultural variable captures religion similarity with Brazil and is a dummy indicating if the country possess Christianity as the majority religion. According to the census of 2010, $87 \%$ of Brazilians are Christians, moreover, Brazil is considered the largest country in the world in number of Catholics (more than 130 million people). ${ }^{5}$ The other cultural variable, language similarity, is a dummy variable that assumes value one if country "k" has an official language of Latin origin (such as Portuguese, Spanish, Italian and French). ${ }^{6}$

The first institutional variable captures the legal origin similarity with Brazil. Legal origin describes how the legal systems aspects (such as property rights mechanisms and contract enforcement provisions) are organized. To establish legal origin similarity we use a dummy indicating if the country follows the "Civil Law" legal system (adopted in Brazil). ${ }^{7}$

Finally, to capture other institutional conditions we created a measure of institutional distance from Brazil based on the "Rule of Law" index of the World Bank. According to the data catalog of the World Bank: "Rule of Law captures perceptions of the extent to which agents have confidence in and abide

\footnotetext{
${ }^{5}$ The countries in our data base that possess other majority religion are: China and Japan (Unaffiliated); South Korea (No clear Majority); India (Hindus); Senegal and Pakistan (Muslims). Source: Hackett et al. (2012).

${ }^{6}$ Brazil's official language is Portuguese. Results do not change if we define language similarity as a Portuguese speaking dummy (not reported).

${ }^{7}$ Countries with other legal systems: Senegal, China, Japan, South Korea, India, Pakistan, Ghana and South Africa (mixed system); EUA, Canada and UK (Common Law). Results do not change if we include mixed system countries into the "Civil Law" classification (not reported).
} 
by the rules of society, and in particular the quality of contract enforcement, property rights, the police, and the courts, as well as the likelihood of crime and violence." Our index is calculated by taking the average differences between country "k" and Brazil of the "Rule of Law" between 2002 and 2016 and then transforming these differences in an index that ranges between 0 and 1 . We attribute the value 1 to the country that possessed during this period the most different institutional environment from Brazil.

According to the results presented in Tables 5.5 and 5.6, regarding cultural distance, only common religion seems to decrease immigrant's network effect on exports (extensive and intensive margins). On the other hand, the institutional distance from Brazil measured by the "Rule of law" increases immigrants' pro-trade effect for both imports and exports. These findings confirm that distant countries, in terms of culture (religion) and institution, experience larger immigrants' network pro-trade effects. 
Table 5.5: Effect of Immigrants on Exports (Countries' characteristics)

\begin{tabular}{|c|c|c|c|c|}
\hline & (OLS) & (PPML) & (OLS) & (PPML) \\
\hline & $\mathrm{I}($ Export $>0)$ & Export & $\mathrm{I}($ Export $>0)$ & Export \\
\hline & \multicolumn{2}{|c|}{ Religious Similarity } & \multicolumn{2}{|c|}{ Language Similarity } \\
\hline Interaction & $\begin{array}{c}-\mathbf{0 . 5 8 5} * * * \\
(0.226)\end{array}$ & $\begin{array}{c}-\mathbf{8 . 0 9 2} \\
(2.862)\end{array}$ & $\begin{array}{c}-\mathbf{0 . 3 1 3} \\
(0.166)\end{array}$ & $\begin{array}{l}-1.473 \\
(1.418)\end{array}$ \\
\hline Immigr_Director_Exp & $\begin{array}{c}1.004^{* * *} \\
(0.208)\end{array}$ & $\begin{array}{c}11.950^{* * *} \\
(2.827)\end{array}$ & $\begin{array}{c}0.634^{* * *} \\
(0.128)\end{array}$ & $\begin{array}{c}5.129 * * * \\
(1.233)\end{array}$ \\
\hline Immigr_NonDirector_Exp & $\begin{array}{c}0.041 \\
(0.357)\end{array}$ & $\begin{array}{l}-9.403 \\
(8.029)\end{array}$ & $\begin{array}{c}0.150 \\
(0.343)\end{array}$ & $\begin{array}{l}-7.862 \\
(8.655)\end{array}$ \\
\hline Immigr & $\begin{array}{c}5.568^{* * *} \\
(1.823)\end{array}$ & $\begin{array}{c}156.282^{* * *} \\
(25.997)\end{array}$ & $\begin{array}{c}5.489^{* * *} \\
(1.819)\end{array}$ & $\begin{array}{c}159.065^{* * *} \\
(27.008)\end{array}$ \\
\hline Observations & 473,427 & 465,781 & 473,427 & 465,781 \\
\hline Municipalities & 2,293 & 2,150 & 2,293 & 2,150 \\
\hline \multirow[t]{2}{*}{ R-squared } & 0.433 & 0.7674 & 0.433 & 0.7673 \\
\hline & \multicolumn{2}{|c|}{ Legal Origin Similarity } & \multicolumn{2}{|c|}{ Institutional Distance } \\
\hline Interaction & $\begin{array}{r}-\mathbf{0 . 0 7 3} \\
(0.231)\end{array}$ & $\begin{array}{l}\mathbf{- 0 . 9 0 9} \\
(1.491)\end{array}$ & $\begin{array}{c}\mathbf{0 . 5 7 4} * * \\
(0.264)\end{array}$ & $\begin{array}{l}\mathbf{- 1 . 6 4 9} \\
(2.272)\end{array}$ \\
\hline Immigr_Director_Exp & $\begin{array}{c}0.534^{* *} \\
(0.211)\end{array}$ & $\begin{array}{c}4.889^{* * *} \\
(1.337)\end{array}$ & $\begin{array}{c}0.164 \\
(0.170)\end{array}$ & $\begin{array}{c}5.146^{* * *} \\
(1.302)\end{array}$ \\
\hline Immigr_NonDirector_Exp & $\begin{array}{c}0.100 \\
(0.363)\end{array}$ & $\begin{array}{l}-7.844 \\
(8.685)\end{array}$ & $\begin{array}{c}0.236 \\
(0.346)\end{array}$ & $\begin{array}{l}-7.793 \\
(8.648)\end{array}$ \\
\hline Immigr & $\begin{array}{c}5.464^{* * *} \\
(1.825)\end{array}$ & $\begin{array}{c}159.154^{* * *} \\
(27.044)\end{array}$ & $\begin{array}{c}5.330^{* * *} \\
(1.807)\end{array}$ & $\begin{array}{c}159.683^{* * *} \\
(27.178)\end{array}$ \\
\hline Observations & 473,427 & 465,781 & 473,427 & 465,781 \\
\hline Municipalities & 2,293 & 2,150 & 2,293 & 2,150 \\
\hline R-squared & 0.433 & 0.7673 & 0.433 & 0.7673 \\
\hline
\end{tabular}

Notes (Table 5.5 ): ${ }^{*}=$ Statistically significant at the 10 percent level. ${ }^{* *}=$ Statistically significant at the 5 percent level. ${ }^{* * *}=$ Statistically significant at the 1 percent level. Robust standard errors are clustered by the pair municipality-country in parentheses. The R-squared for equations estimated with PPML is the Pseudo-R-squared. Dependent variables are a dummy indicating if municipality "i" exported to "k" during "t" $(I($ Export $>0))$ and the value exported (Export). Immigr is the share of workers of " $\mathrm{i}$ " that are immigrants from "k", Immigr_Director_Exp is the share management positions in exporting firms of " $\mathrm{i}$ " occupied by immigrants from "k" and Immigr_NonDirector_Exp is the share of non-management positions in exporting firms of "i" occupied by immigrants from "k". The most important independent variables is Interaction that is the product of Immigr_Director_Exp with variables indicating religious similarity, language similarity, legal origin similarity or institutional distance from Brazil. Religious similarity $=$ dummy if Christianity is the main religion in "k". Language Similarity= dummy if a language 
Notes (Table 5.5) (continuation): of latin origin (portuguese, spanish, italian and french in our case) is spoken in "k". Legal Origin Similarity= dummy indicating if "k" possesses a "Civil Law"legal system origin. Institutional Distance $=$ an index between 0 and 1 calculated according to the average differences between " $\mathrm{k}$ " and Brazil of the "Rule of Law" index (measured by World Bank) between 2000 and 2016, therefore, the value 1 is attributed to the country that possess the most different institutional environment compared with Brazil during this period. All regressions include as additional independent variables (not shown): the product of the GDP's of "i" and "k", the distance between municipality "i" and the capital of country "k" and a constant. Finally, all regressions are estimated considering municipality, state-year and country-state fixed effects.

Table 5.6: Effect of Immigrants on Imports (Countries' characteristics)

\begin{tabular}{|c|c|c|c|c|}
\hline & $\begin{array}{c}(\text { OLS }) \\
\text { I }(\text { Import }>0)\end{array}$ & $\begin{array}{c}\text { (PPML) } \\
\text { Import }\end{array}$ & $\begin{array}{c}(\text { OLS }) \\
\text { I }(\text { Import }>0)\end{array}$ & $\begin{array}{c}\text { (PPML) } \\
\text { Import }\end{array}$ \\
\hline & \multicolumn{2}{|c|}{ Religious Similarity } & \multicolumn{2}{|c|}{ Language Similarity } \\
\hline Interaction & $\begin{array}{l}-\mathbf{0 . 3 7 0} \\
(0.229)\end{array}$ & $\begin{array}{l}\text { 6.269* } \\
(3.302)\end{array}$ & $\begin{array}{l}-\mathbf{0 . 2 2 8} \\
(0.187)\end{array}$ & $\begin{array}{c}3.054 \\
(3.025)\end{array}$ \\
\hline Immigr_Director_Imp & $\begin{array}{c}0.870^{* * *} \\
(0.209)\end{array}$ & $\begin{array}{c}1.816 \\
(3.194)\end{array}$ & $\begin{array}{c}0.685^{* * *} \\
(0.130)\end{array}$ & $\begin{array}{l}5.132^{*} \\
(2.804)\end{array}$ \\
\hline Immigr_NonDirector_Imp & $\begin{array}{c}0.133 \\
(0.314)\end{array}$ & $\begin{array}{c}-8.775 \\
(13.313)\end{array}$ & $\begin{array}{c}0.173 \\
(0.314)\end{array}$ & $\begin{array}{c}-8.720 \\
(10.182)\end{array}$ \\
\hline Immigr & $\begin{array}{l}2.532^{* *} \\
(1.134) \\
\end{array}$ & $\begin{array}{c}155.942^{* * *} \\
(45.074)\end{array}$ & $\begin{array}{l}2.550^{* *} \\
(1.149) \\
\end{array}$ & $\begin{array}{c}137.839^{* * *} \\
(37.635)\end{array}$ \\
\hline Observations & 440,555 & 430,361 & 440,555 & 430,361 \\
\hline Municipalities & 2,217 & 2,102 & 2,217 & 2,102 \\
\hline \multirow[t]{2}{*}{ R-squared } & 0.486 & 0.8630 & 0.486 & 0.8628 \\
\hline & \multicolumn{2}{|c|}{ Legal Origin Similarity } & \multicolumn{2}{|c|}{ Institutional Distance } \\
\hline Interaction & $\begin{array}{l}-\mathbf{0 . 1 8 1} \\
(0.206)\end{array}$ & $\begin{array}{c}\mathbf{5 . 4 0 8} \\
(3.339)\end{array}$ & $\begin{array}{c}\mathbf{0 . 7 2 7} * * \\
(0.302)\end{array}$ & $\begin{array}{l}\text { 6.593* } \\
(3.817)\end{array}$ \\
\hline Immigr_Director_Imp & $\begin{array}{c}0.701^{* * *} \\
(0.180)\end{array}$ & $\begin{array}{c}2.678 \\
(3.195)\end{array}$ & $\begin{array}{c}0.208 \\
(0.171)\end{array}$ & $\begin{array}{c}2.584 \\
(3.077)\end{array}$ \\
\hline Immigr_NonDirector_Imp & $\begin{array}{c}0.152 \\
(0.313)\end{array}$ & $\begin{array}{c}-8.381 \\
(12.180)\end{array}$ & $\begin{array}{c}0.206 \\
(0.309)\end{array}$ & $\begin{array}{c}-4.325 \\
(11.628)\end{array}$ \\
\hline Immigr & $\begin{array}{l}2.547^{* *} \\
(1.144)\end{array}$ & $\begin{array}{c}150.616^{* * *} \\
(42.042)\end{array}$ & $\begin{array}{l}2.545^{* *} \\
(1.147)\end{array}$ & $\begin{array}{c}133.218^{* * *} \\
(38.784)\end{array}$ \\
\hline Observations & 440,555 & 430,361 & 440,555 & 430,361 \\
\hline Municipalities & 2,217 & 2,102 & 2,217 & 2,102 \\
\hline R-squared & 0.486 & 0.8629 & 0.486 & 0.8628 \\
\hline
\end{tabular}

Notes (Table 5.6): $*=$ Statistically significant at the 10 percent level. ${ }^{* *}=$ Statistically significant at the 5 percent level. $* * *=$ Statistically significant at the 1 percent level. Robust 
Notes(Table 5.6) (continuation): standard errors are clustered by the pair municipalitycountry in parentheses. The R-squared for equations estimated with PPML is the PseudoR-squared. Dependent variables are a dummy indicating if municipality "i" imported to "k" during "t" (I(Import > 0)) and the value imported (Import). Immigr is the share of workers of " $\mathrm{i}$ " that are immigrants from " $\mathrm{k}$ ", Immigr_Director_Imp is the share management positions in importing firms of "i" occupied by immigrants from " $k$ " and Immigr_NonDirector_Imp is the share of non-management positions in importing firms of "i" occupied by immigrants from "k". The most important independent variables is Interaction that is the product of Immigr_Director_Imp with variables indicating religious similarity, language similarity, legal origin similarity or institutional distance from Brazil. Religious similarity= dummy if Christianity is the main religion in "k". Language Similarity = dummy if a language of latin origin (portuguese, spanish, italian and french in our case) is spoken in "k". Legal Origin Similarity= dummy indicating if "k" possesses a "Civil Law"legal system origin. Institutional Distance $=$ an index between 0 and 1 calculated according to the average differences between "k" and Brazil of the "Rule of Law" index (measured by World Bank) between 2000 and 2016, therefore, the value 1 is attributed to the country that possess the most different institutional environment compared with Brazil during this period. All regressions include as additional independent variables (not shown): the product of the GDP's of "i" and "k", the distance between municipality "i" and the capital of country "k" and a constant. Finally, all regressions are estimated considering municipality, state-year and country-state fixed effects.

\section{5}

\section{Robustness Tests}

\subsection{1 \\ Weighted Immigration Variables}

The labor contracts data also provide information on which range are the total values exported and imported by each employer firm during year "t". The first column of Table 5.7 describes these ranges available in the data. With this information we can attribute different weights to the labor contracts in municipality " $\mathrm{i}$ " according to how much the employer firm traded during year "t". Therefore, we can recalculate variables Immigr_Director_Exp, Immigr_Director_Imp, Immigr_NonDirector_Exp and Immigr_NonDirector_Imp giving more weight to workers employed by firms that export and import more. ${ }^{8}$ We used two different weighting strategies described by columns 2 and 3 of Table 5.7. With the first set of weights, "P", we obtained the variables PImmigr_Director_Exp, PImmigr_Director_Imp, PImmigr_NonDirector_Exp and PImmigr_NonDirector_Imp. Using "P2" weights we calculated the variables P2Immigr_Director_Exp, P2Immigr_Director_Imp, P2Immigr_NonDirector_Exp and

${ }^{8}$ It is not possible to recalculate variable Immigr because the weights are, obviously, only available for contracts in which the employer firm trades internationally. 
P2Immigr_NonDirector_Imp. All the new immigration variables kept assuming values between 0 and 1 , because we weight all the labor contracts, in municipality "i", of importer/exporter firms with Brazilians and with foreigners (see Table A.5 to see an example of the weighted immigration variables calculation).

Table 5.7: Weights description

\begin{tabular}{|l|c|c|}
\hline Exports or Imports Value Ranges & Weight "P" & Weight "P2" \\
\hline Zero & 0 & 0 \\
\hline up to 1 million & 1 & 0.5 \\
\hline Between 1 and 5 millions & 2 & 2.5 \\
\hline Between 5 and 10 millions & 3 & 7.5 \\
\hline Between 10 and 50 millions & 4 & 30 \\
\hline Between 50 and 100 millions & 5 & 75 \\
\hline More than 100 millions & 6 & 100 \\
\hline
\end{tabular}

Note: The range of the value exported or imported refers, as the information whether the firm exported or imported during year "t", to trade with all countries that the firm have business relation, in other words, it is not specific to a nationality.

According to the results presented in Table 5.8, all immigrants' network variables (PImmigr_Director_Exp, P2Immigr_Director_Exp, PImmigr_Director_Imp and P2Immigr_Director_Imp) continue to be positive and statistically significant at $5 \%$ for both extensive and intensive margin. Furthermore, PImmigr_NonDirector_Exp, P2Immigr_NonDirector_Exp, PImmigr_NonDirector_Imp and P2Immigr_NonDirector_Imp remain not significant. 
Table 5.8: Effect of Immigrants on Exports and Imports (Weighted Immigration Variables)

\begin{tabular}{|c|c|c|c|c|c|c|}
\hline & OLS & OLS & PPML & PPML & OLS & OLS \\
\hline Panel A. & $\mathrm{I}($ Export $>0)$ & $\mathrm{I}($ Export $>0)$ & Export & Export & $\ln ($ Export+1) & $\ln ($ Export +1$)$ \\
\hline \multirow[t]{2}{*}{ PImmigr_Director_Exp } & $0.461^{* * *}$ & & $2.37^{* * *}$ & & $6.446^{* * *}$ & \\
\hline & $(0.082)$ & & $(0.79)$ & & $(1.160)$ & \\
\hline \multirow[t]{2}{*}{ PImmigr_NonDirector_Exp } & 0.221 & & -4.94 & & -2.140 & \\
\hline & $(0.361)$ & & $(6.69)$ & & $(5.850)$ & \\
\hline \multirow[t]{2}{*}{ P2Immigr_Director_Exp } & & $0.415^{* * *}$ & & $2.52^{* * *}$ & & $6.019^{* * *}$ \\
\hline & & $(0.075)$ & & $(0.76)$ & & $(1.078)$ \\
\hline \multirow[t]{2}{*}{ P2Immigr_NonDirector_Exp } & & 0.410 & & -0.68 & & 2.724 \\
\hline & & $(0.338)$ & & $(4.82)$ & & $(6.046)$ \\
\hline \multirow[t]{2}{*}{ Immigr } & $5.268^{* * *}$ & $5.023^{* * *}$ & $159.44^{* * *}$ & $152.33^{* * *}$ & $99.561^{* * *}$ & $92.213^{* * *}$ \\
\hline & $(1.820)$ & $(1.784)$ & $(27.46)$ & $(27.56)$ & $(29.432)$ & $(28.542)$ \\
\hline \multirow[t]{2}{*}{$\ln \left(\mathrm{GDP} \_\right.$Masses $)$} & $0.093^{* * *}$ & $0.093^{* * *}$ & $1.21^{* * *}$ & $1.21^{* * *}$ & $1.532^{* * *}$ & $1.532^{* * *}$ \\
\hline & $(0.004)$ & $(0.004)$ & $(0.07)$ & $(0.07)$ & $(0.055)$ & $(0.055)$ \\
\hline \multirow[t]{2}{*}{$\ln ($ DISTANCE) } & $-0.066^{* *}$ & $-0.066^{* *}$ & -0.18 & -0.21 & -0.377 & -0.379 \\
\hline & $(0.028)$ & $(0.028)$ & $(0.73)$ & $(0.73)$ & $(0.375)$ & $(0.375)$ \\
\hline Observations & 473,427 & 473,427 & 465,781 & 465,781 & 473,427 & 473,427 \\
\hline R-squared & 0.433 & 0.433 & 0.767 & 0.767 & 0.488 & 0.488 \\
\hline Municipalities & 2,293 & 2,293 & 2,150 & 2,150 & 2,293 & 2,293 \\
\hline Ramsey Test p-value & & & 0.1522 & 0.1426 & 0.000 & 0.000 \\
\hline $\operatorname{Mean}(\mathrm{Y})$ & 0.383 & 0.383 & $3,430,611$ & $3,430,611$ & & \\
\hline Mean(*Immigr_Director_Exp) & 0.0007 & 0.0007 & 0.0007 & 0.0007 & 0.0007 & 0.0007 \\
\hline sd(*Immigr_Director_Exp $)$ & 0.0141 & 0.0148 & 0.0138 & 0.0145 & 0.0141 & 0.0148 \\
\hline Panel B. & $\mathrm{I}($ Import $>0)$ & $\mathrm{I}($ Import $>0)$ & Import & Import & $\ln ($ Import+1) & $\ln ($ Import +1$)$ \\
\hline \multirow[t]{2}{*}{ PImmigr_Director_Imp } & $0.552^{* * *}$ & & $2.94^{* * *}$ & & $9.559^{* * *}$ & \\
\hline & $(0.089)$ & & $(0.98)$ & & $(1.328)$ & \\
\hline \multirow[t]{2}{*}{ PImmigr_NonDirector_Imp } & 0.255 & & 3.45 & & 7.803 & \\
\hline & $(0.320)$ & & $(11.65)$ & & $(5.174)$ & \\
\hline \multirow[t]{2}{*}{ P2Immigr_Director_Imp } & & $0.513^{* * *}$ & & $3.37^{* * *}$ & & $9.695^{* * *}$ \\
\hline & & $(0.079)$ & & $(0.92)$ & & $(1.219)$ \\
\hline \multirow[t]{2}{*}{ P2Immigr_NonDirector_Imp } & & 0.415 & & 8.91 & & $11.258^{* *}$ \\
\hline & & $(0.332)$ & & $(9.66)$ & & $(5.405)$ \\
\hline \multirow[t]{2}{*}{ Immigr } & $2.524^{* *}$ & $2.482^{* *}$ & $144.75^{* * *}$ & $139.14^{* * *}$ & 37.178 & 35.768 \\
\hline & $(1.134)$ & $(1.106)$ & $(34.23)$ & $(38.52)$ & $(23.118)$ & $(22.089)$ \\
\hline \multirow[t]{2}{*}{$\ln \left(\mathrm{GDP} \_\right.$Masses $)$} & $0.098^{* * *}$ & $0.098^{* * *}$ & $0.98^{* * *}$ & $0.97^{* * *}$ & $1.502^{* * *}$ & $1.502^{* * *}$ \\
\hline & $(0.004)$ & $(0.004)$ & $(0.08)$ & $(0.08)$ & $(0.051)$ & $(0.051)$ \\
\hline \multirow[t]{2}{*}{$\ln ($ DISTANCE) } & $-0.461^{* * *}$ & $-0.461^{* * *}$ & $-4.66^{* * *}$ & $-4.68^{* * *}$ & $-6.686^{* * *}$ & $-6.685^{* * *}$ \\
\hline & $(0.028)$ & $(0.028)$ & $(0.60)$ & $(0.60)$ & $(0.398)$ & $(0.398)$ \\
\hline Observations & 440,555 & 440,555 & 430,361 & 430,361 & 440,555 & 440,555 \\
\hline R-squared & 0.486 & 0.486 & 0.863 & 0.864 & 0.564 & 0.564 \\
\hline Municipalities & 2,217 & 2,217 & 2,102 & 2,102 & 2,217 & 2,217 \\
\hline Ramsey Test p-value & & & 0.0398 & 0.0277 & 0.0149 & 0.0157 \\
\hline $\operatorname{Mean}(\mathrm{Y})$ & 0.336 & 0.336 & $3,388,481$ & $3,388,481$ & & \\
\hline Mean $\left({ }^{*}\right.$ Immigr_Director_Imp $)$ & 0.0008 & 0.0008 & 0.0008 & 0.0008 & 0.0008 & 0.0008 \\
\hline sd(*Immigr_Director_Imp) & 0.0143 & 0.0152 & 0.0143 & 0.0151 & 0.0143 & 0.0152 \\
\hline Municipality FE & YES & YES & YES & YES & YES & YES \\
\hline State-Year FE & YES & YES & YES & YES & YES & YES \\
\hline State-Country FE & YES & YES & YES & YES & YES & YES \\
\hline
\end{tabular}

Notes (Table 5.8): ${ }^{*}=$ Statistically significant at the 10 percent level. ${ }^{* *}=$ Statistically significant at the 5 percent level. ${ }^{* *}=$ Statistically significant at the 1 percent level. Robust standard errors clustered by the pair municipality-country in parentheses. OLS $=$ Ordinary Least Squares. PPML = Pseudo Poisson Maximum Likelihood. The R-squared for equations estimated with PPML is the Pseudo-R-squared. The Ramsey test is calculated accordingly 
Notes (Table 5.8) (continuation): to Silva and Tenreyro (2006). Dependent variables are a dummy indicating if municipality "i" exported to "k" during "t" $(I($ Export $>0))$, the value exported (Export), the logarithm of the value exported plus $1(\ln ($ Export +1$))$, a dummy indicating if municipality "i" imported to "k" during "t" $(I($ Import $>0))$, the value imported (Import) and the logarithm of the value imported plus $1(\ln ($ Import +1$))$. Immigr is the share of workers of " $\mathrm{i}$ " that are immigrants from "k". PImmigr_Director_Exp and P2Immigr_Director_Exp are the weighted share management positions in exporting firms of "i" occupied by immigrants from "k" using weights "P" and "P2", respectively. PImmigr_Director_Imp and P2Immigr_Director_Imp are the weighted share management positions in importing firms of "i" occupied by immigrants from "k" using weights "P" and "P2", respectively. PImmigr_NonDirector_Exp and P2Immigr_NonDirector_Exp are the weighted share non-management positions in exporting firms of "i" occupied by immigrants from "k" using weights "P" and "P2", respectively. PImmigr_NonDirector_Imp and P2Immigr_NonDirector_Imp are the weighted share non-management positions in importing firms of "i" occupied by immigrants from "k" using weights "P" and "P2", respectively.

\section{5 .2}

\section{Frontier Effect}

According to the geographical distribution of the immigration variables (Figure 2.1 in Section 2 and Figures A.1 to A.6 in the Appendix), there are some concentrations of foreigners in municipalities that border other South American countries. This is more visible when we look to the distribution of a specific nationality. Figure 5.1 bellow illustrates the distribution of Paraguayans, we can see that immigrants occupying management positions in exporting/importing firms do not concentrate in the borders with Paraguay. However, to confirm that our immigrants' network variables are not capturing a simple distance/frontier effect we estimate equations 3-1 and 3-2 using only countries that do not border Brazil.

The results are presented in Table 5.9. Both variables capturing immigrants' network effect ("Immigr_Director_Exp" and "Immigr_Director_Imp") still positive and significant corroborating the pro-trade immigration effect for both exports and imports (intensive and extensive margins). However, variable "Immigr" lost significance and is smaller when compared with the results of Table 5.1, indicating that it was indeed capturing in part a frontier effect. ${ }^{9}$

\footnotetext{
${ }^{9}$ To deal with frontier effects with another strategy, we also added a dummy variable if municipality " $\mathrm{i}$ " shared a border with country " $\mathrm{k}$ " in equations $3-1$ and $3-2$. The results did not change (not reported).
} 
Figure 5.1: Paraguayan immigrants' distribution in 2016

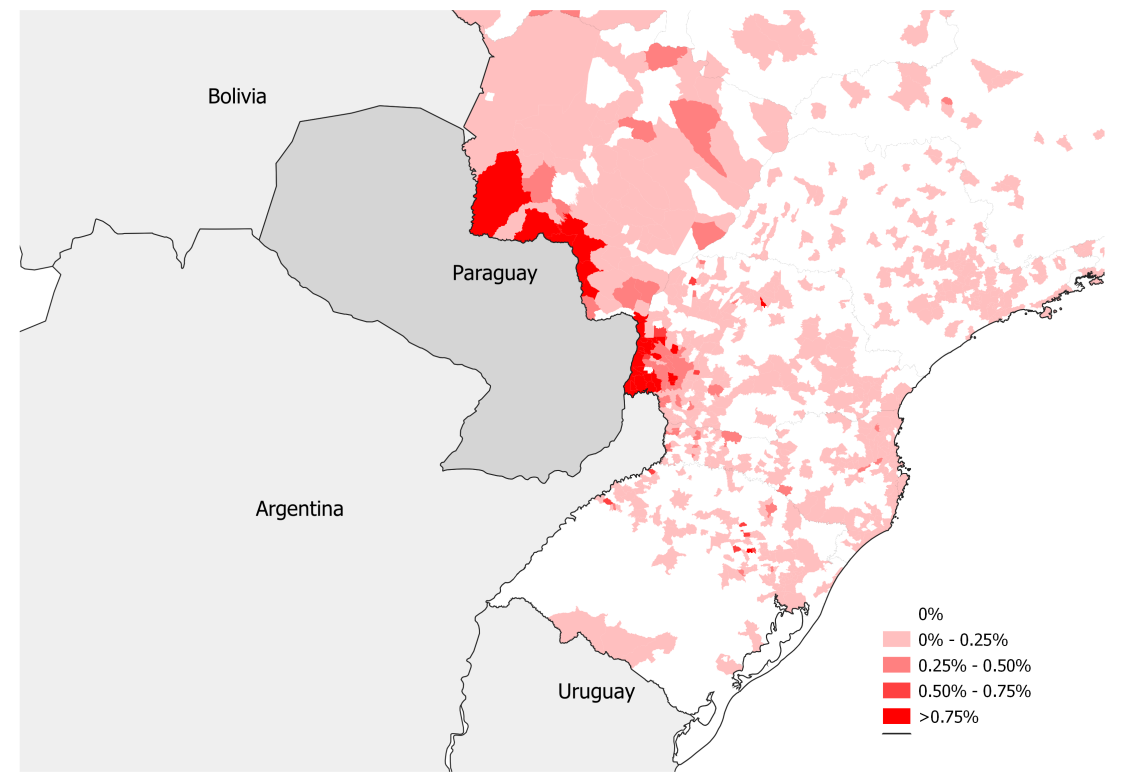

Immigr

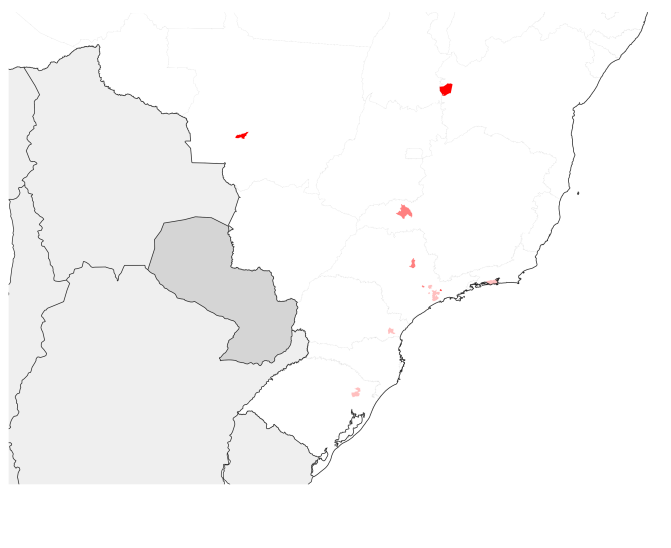

Immigr_Director_Exp

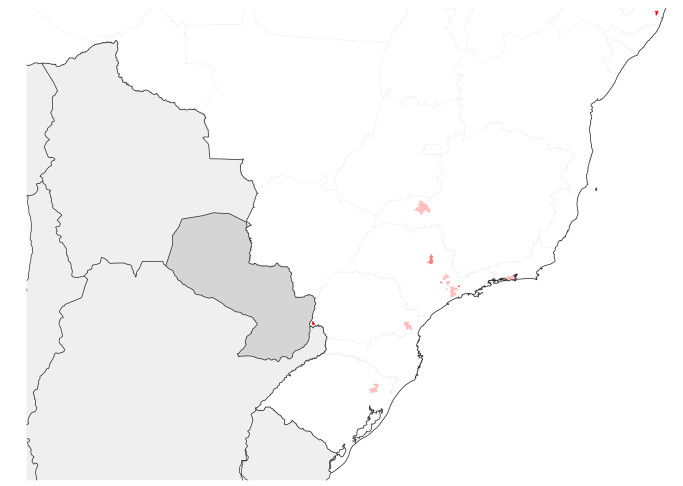

Immigr_Director_Imp

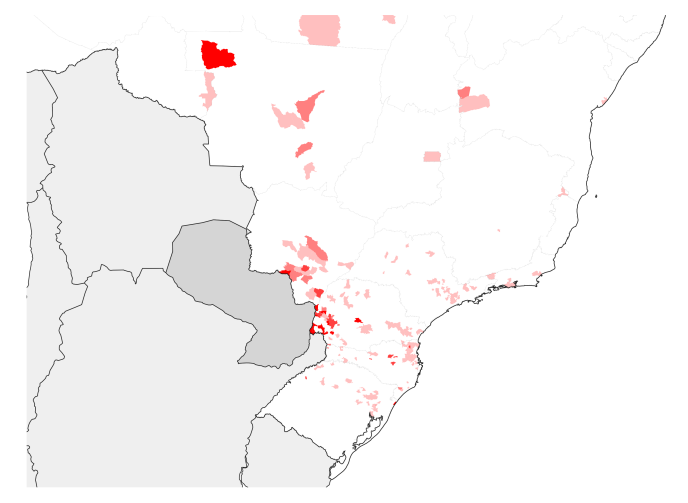

Immigr_NonDirector_Exp

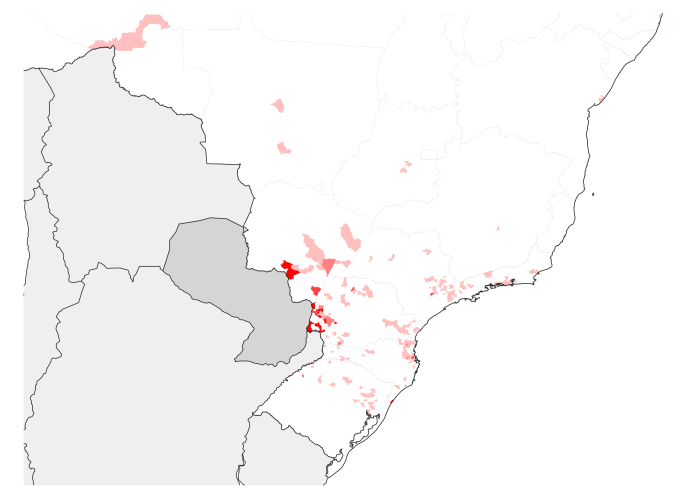

Immigr_NonDirector_Imp 
Table 5.9: Effect of Immigrants on Exports and Imports (Excluding neighboring countries)

\begin{tabular}{|c|c|c|c|c|c|}
\hline & OLS & OLS & PPML & PPML & OLS \\
\hline Panel A. & $\mathrm{I}($ Export $>0)$ & $\mathrm{I}($ Export $>0)$ & Export & Export & $\ln ($ Export +1$)$ \\
\hline \multirow[t]{2}{*}{ Immigr_Director_Exp } & $0.726^{* * *}$ & $0.689^{* * *}$ & $4.178^{* * *}$ & $4.19^{* * *}$ & $9.060^{* * *}$ \\
\hline & $(0.086)$ & $(0.085)$ & $(0.779)$ & $(0.73)$ & $(1.232)$ \\
\hline \multirow[t]{2}{*}{ Immigr_NonDirector_Exp } & $1.404^{* *}$ & $1.283^{* *}$ & $10.398^{* *}$ & 5.72 & 13.097 \\
\hline & $(0.585)$ & $(0.530)$ & $(4.080)$ & $(4.06)$ & $(8.910)$ \\
\hline \multirow[t]{2}{*}{ Immigr } & $2.904^{*}$ & 0.904 & $141.986^{* * *}$ & $131.66^{* * *}$ & 21.701 \\
\hline & $(1.634)$ & $(1.486)$ & $(22.383)$ & $(30.84)$ & $(21.332)$ \\
\hline \multirow[t]{2}{*}{$\ln \left(\mathrm{GDP} \_\right.$Masses $)$} & $0.097^{* * *}$ & $0.099^{* * *}$ & $1.265^{* * *}$ & $1.31^{* * *}$ & $1.611^{* * *}$ \\
\hline & $(0.005)$ & $(0.005)$ & $(0.071)$ & $(0.08)$ & $(0.065)$ \\
\hline \multirow[t]{2}{*}{$\ln ($ DISTANCE $)$} & $-0.151^{* * *}$ & $0.256^{* * *}$ & -0.027 & 2.64 & $4.321^{* * *}$ \\
\hline & $(0.015)$ & $(0.071)$ & $(0.520)$ & $(1.87)$ & $(0.965)$ \\
\hline Observations & 365,790 & 365,790 & 356,025 & 354,437 & 365,790 \\
\hline Municipalities & 2,293 & 2,293 & 2,048 & 2,048 & 2,293 \\
\hline R-squared & 0.414 & 0.434 & 0.738 & 0.785 & 0.486 \\
\hline Ramsey Test p-value & & & 0.8255 & 0.2795 & 0.000 \\
\hline Panel B. & $\mathrm{I}($ Import >0) & $\mathrm{I}($ Import $>0)$ & Import & Import & $\ln ($ Import +1$)$ \\
\hline \multirow[t]{2}{*}{ Immigr_Director_Imp } & $0.753^{* * *}$ & $0.708^{* * *}$ & $6.331^{* *}$ & 3.16 & $11.516^{* * *}$ \\
\hline & $(0.092)$ & $(0.089)$ & $(3.197)$ & $(2.87)$ & $(1.263)$ \\
\hline \multirow[t]{2}{*}{ Immigr_NonDirector_Imp } & 0.197 & 0.171 & 28.286 & -2.97 & 1.724 \\
\hline & $(0.398)$ & $(0.382)$ & $(57.517)$ & $(15.61)$ & $(5.056)$ \\
\hline \multirow[t]{2}{*}{ Immigr } & -0.372 & -1.397 & 11.363 & $614.07^{* * *}$ & -0.999 \\
\hline & $(1.586)$ & $(1.667)$ & $(86.347)$ & $(114.52)$ & $(20.468)$ \\
\hline \multirow[t]{2}{*}{$\ln \left(\mathrm{GDP} \_\right.$Masses $)$} & $0.131^{* * *}$ & $0.131^{* * *}$ & $1.135^{* * *}$ & $0.98^{* * *}$ & $1.981^{* * *}$ \\
\hline & $(0.005)$ & $(0.005)$ & $(0.086)$ & $(0.08)$ & $(0.060)$ \\
\hline \multirow[t]{2}{*}{$\ln ($ DISTANCE $)$} & $-0.059^{* * *}$ & $-0.170^{* *}$ & 0.518 & 0.04 & $-1.869^{* *}$ \\
\hline & $(0.015)$ & $(0.066)$ & $(0.965)$ & $(2.79)$ & $(0.875)$ \\
\hline Observations & 340,123 & 340,123 & 333,698 & 327,314 & 340,123 \\
\hline Municipalities & 2,217 & 2,217 & 2,021 & 2,021 & 2,217 \\
\hline R-squared & 0.496 & 0.506 & 0.833 & 0.876 & 0.594 \\
\hline Ramsey Test p-value & & & 0.0277 & 0.7129 & 0.000 \\
\hline Year FE & YES & & "YES & & \\
\hline Country FE & YES & & YES & & \\
\hline Municipality FE & YES & YES & YES & YES & YES \\
\hline State-Year FE & & YES & & YES & YES \\
\hline State-Country FE & & YES & & YES & YES \\
\hline
\end{tabular}

Notes (Table 5.9): * = Statistically significant at the 10 percent level. ${ }^{* *}=$ Statistically significant at the 5 percent level. ${ }^{* * *}=$ Statistically significant at the 1 percent level. Robust standard errors are clustered by the pair municipality-country in parentheses. OLS=Ordinary Least Squares. PPML $=$ Pseudo Poisson Maximum Likelihood. The R-squared for equations estimated with PPML is the Pseudo-R-squared. The Ramsey test is calculated accordingly to Silva and Tenreyro (2006). Dependent variables are a dummy indicating if municipality "i" exported to "k" during "t" (I(Export $>0))$, the value exported (Export), the logarithm of the value exported plus $1(\ln ($ Export +1$))$, a dummy indicating if municipality "i" imported to "k" 
Notes (Table 5.9) (continuation): during "t" (I(Import $>0))$, the value imported (Import) and the logarithm of the value imported plus $1(\ln ($ Import +1$))$. Immigr is the share of workers of "i" that are immigrants from "k", Immigr_Director_Exp (Immigr_Director_Imp) is the share of management positions in exporting (importing) firms of "i" occupied by immigrants from "k". Immigr_NonDirector_Exp(Immigr_NonDirector_Imp) is the share of non-management positions in exporting (importing) firms of "i" occupied by immigrants from "k". 


\section{6}

\section{Conclusion}

Understanding the immigrant's network effects on trade is important for different reasons. First, immigration (if the networking effect is positive and significant) can enable Brazilian economy to achieve its potential as exporter and importer. Second, it can be relevant for the calculations of costs and benefits of immigration. Finally, the enhance of trade creates utility-increasing consumption opportunities for the non-migrants in both countries.

This paper used detailed municipality trade data yet not explored by literature. We proposed a more precise measure of immigrants' network by exploring immigrants' occupation and whether the employer firm exported or imported. Moreover, we assessed this matter in a developing economy context. By estimating augmented gravity equations we found that immigrants occupying managing positions in importing/exporting firms (a proxy for immigrants' networks) increase municipalities imports and exports (extensive and intensive margin). Indeed, immigrants occupying non-management positions, as expected, do not affect trade since they do not have space to use their protrade specific human capital. Therefore, policies that favor the movement of highly skilled individuals and facilitates hiring foreigners would intensify trade.

Additionally, imports seem to be more affected by immigrants' network than exports. Using alternative measures of intensive and extensive margins, we also showed that immigrants increase exports and imports product variety. Following the literature we examined heterogeneous immigrants' network effect among types of products and countries characteristics. First, as expected, exports and imports of differentiated products are more enhanced by immigrants than non-differentiated. Second, our results also confirmed that culturally (in terms of religion beliefs) and institutionally distant countries from Brazil benefit the most with the pro-trade effect of immigration. This heterogeneous effects corroborate the idea that immigrants indeed enhance trade by proving information and bilateral trust. Moreover, our results are robust for weighting the immigration variables with the firm's total export and import values. We also showed that the estimations are not capturing border effects.

Finally, this paper can't (and does not intend to) identify the general effect of immigration flows on trade, we capture only the trade effect of 
employing immigrants in specific positions. Therefore, we can't, for example, determine the effects of opening borders to foreigners on Brazilian trade balance. 


\section{Bibliography}

Aleksynska, M. and Peri, G. (2014). Isolating the network effect of immigrants on trade. The World Economy, 37(3):434-455.

Allen, T. (2014). Information frictions in trade. Econometrica, 82(6):2041-2083.

Anderson, J. E. and Van Wincoop, E. (2004). Trade costs. Journal of Economic literature, 42(3):691-751.

Bandyopadhyay, S., Coughlin, C. C., and Wall, H. J. (2008). Ethnic networks and us exports. Review of International Economics, 16(1):199-213.

Bergstrand, J. H. (1985). The gravity equation in international trade: some microeconomic foundations and empirical evidence. The review of economics and statistics, pages 474-481.

Bernard, A. B. and Jensen, J. B. (2004). Why some firms export. Review of economics and Statistics, 86(2):561-569.

Combes, P.-P., Lafourcade, M., and Mayer, T. (2005). The trade-creating effects of business and social networks: evidence from france. Journal of international Economics, 66(1):1-29.

Dunlevy, J. A. (2006). The influence of corruption and language on the protrade effect of immigrants: Evidence from the american states. Review of Economics and Statistics, 88(1):182-186.

Dunlevy, J. A. and Hutchinson, W. K. (1999). The impact of immigration on american import trade in the late nineteenth and early twentieth centuries. The Journal of Economic History, 59(4):1043-1062.

Dutt, P., Mihov, I., and Van Zandt, T. (2013). The effect of wto on the extensive and the intensive margins of trade. Journal of international Economics, 91(2):204-219.

Felbermayr, G. J. and Jung, B. (2009). The pro-trade effect of the brain drain: Sorting out confounding factors. Economics Letters, 104(2):72-75. 
Genc, M., Gheasi, M., Nijkamp, P., Poot, J., et al. (2012). The impact of immigration on international trade: a meta-analysis. Migration impact assessment: New horizons, 301.

Girma, S. and Yu, Z. (2002). The link between immigration and trade: Evidence from the united kingdom. Weltwirtschaftliches Archiv, 138(1):115-130.

Gould, D. M. (1994). Immigrant links to the home country: empirical implications for us bilateral trade flows. The Review of Economics and Statistics, pages 302-316.

Guiso, L., Sapienza, P., and Zingales, L. (2009). Cultural biases in economic exchange? The Quarterly Journal of Economics, 124(3):1095-1131.

Hackett, C., Grim, B., Stonawski, M., Skirbekk, V., Potančoková, M., and Abel, G. (2012). The global religious landscape. Washington, DC: Pew Research Center.

Head, K. and Ries, J. (1998). Immigration and trade creation: econometric evidence from canada. Canadian journal of economics, pages 47-62.

Jaeger, D. A., Ruist, J., and Stuhler, J. (2018). Shift-share instruments and the impact of immigration. Technical report, National Bureau of Economic Research.

Kahouli, B. and Maktouf, S. (2015). The determinants of fdi and the impact of the economic crisis on the implementation of rtas: A static and dynamic gravity model. International Business Review, 24(3):518-529.

Martinez-Zarzoso, I., Felicitas, N.-L. D., and Horsewood, N. (2009). Are regional trading agreements beneficial?: Static and dynamic panel gravity models. The North American Journal of Economics and Finance, 20(1):46-65.

Morse, A. and Shive, S. (2011). Patriotism in your portfolio. Journal of financial markets, 14(2):411-440.

Mundra, K. (2005). Immigration and international trade: A semiparametric empirical investigation. The Journal of International Trade \& Economic Development, 14(1):65-91.

Ottaviano, G. I., Peri, G., and Wright, G. C. (2018). Immigration, trade and productivity in services: Evidence from uk firms. Journal of International Economics, 112:88-108.

Parsons, C. and Vézina, P.-L. (2018). Migrant networks and trade: The vietnamese boat people as a natural experiment. The Economic Journal, 128(612):F210F234. 
Peri, G. and Requena-Silvente, F. (2010). The trade creation effect of immigrants: evidence from the remarkable case of spain. Canadian Journal of Economics/Revue canadienne d'économique, 43(4):1433-1459.

Rauch, J. E. (1999). Networks versus markets in international trade. Journal of international Economics, 48(1):7-35.

Rauch, J. E. and Trindade, V. (2002). Ethnic chinese networks in international trade. Review of Economics and Statistics, 84(1):116-130.

Schmeiser, K. N. (2012). Learning to export: Export growth and the destination decision of firms. Journal of International Economics, 87(1):89-97.

Silva, J. S. and Tenreyro, S. (2006). The log of gravity. The Review of Economics and statistics, 88(4):641-658.

Steingress, W. (2015). The causal impact of migration on us trade: Evidence from a natural experiment. 
Table A.1: Countries' participation on Brazilian trade flows

\begin{tabular}{|c|c|c|c|c|c|c|c|c|}
\hline & \multicolumn{4}{|c|}{ Imports } & \multicolumn{4}{|c|}{ Exports } \\
\hline Country & $\% 2016$ & $\max \%$ & $\min \%$ & mean $\%$ & $\% 2016$ & $\max \%$ & $\min \%$ & mean $\%$ \\
\hline USA & 17.00 & 23.00 & 15.00 & 17.00 & 13.00 & 26.00 & 9.70 & 16.00 \\
\hline China & 17.00 & 18.00 & 2.20 & 11.00 & 19.00 & 19.00 & 2.00 & 11.00 \\
\hline Germany & 6.70 & 9.40 & 6.10 & 7.40 & 2.60 & 4.70 & 2.60 & 3.90 \\
\hline Argentina & 6.60 & 12.00 & 6.00 & 8.40 & 7.30 & 12.00 & 3.90 & 8.10 \\
\hline South Korea & 4.00 & 4.70 & 2.20 & 3.40 & 1.60 & 2.00 & 1.10 & 1.60 \\
\hline France & 2.70 & 3.70 & 2.40 & 3.00 & 1.30 & 3.20 & 1.20 & 2.00 \\
\hline Italy & 2.70 & 3.90 & 2.70 & 3.00 & 1.80 & 4.00 & 1.70 & 2.50 \\
\hline Japan & 2.60 & 5.50 & 2.60 & 4.00 & 2.50 & 4.60 & 2.50 & 3.20 \\
\hline Chile & 2.10 & 3.10 & 1.40 & 2.10 & 2.20 & 3.10 & 1.80 & 2.40 \\
\hline Spain & 1.90 & 2.20 & 1.40 & 1.80 & 1.40 & 2.10 & 1.40 & 1.80 \\
\hline India & 1.80 & 2.90 & 0.49 & 1.80 & 1.70 & 2.30 & 0.40 & 1.20 \\
\hline UK & 1.70 & 2.80 & 1.40 & 1.80 & 1.50 & 3.00 & 1.50 & 2.20 \\
\hline Russia & 1.50 & 1.90 & 0.84 & 1.20 & 1.30 & 2.50 & 0.78 & 1.80 \\
\hline Canada & 1.40 & 2.00 & 1.20 & 1.50 & 1.30 & 1.70 & 0.97 & 1.30 \\
\hline Switzerland & 1.40 & 1.90 & 1.20 & 1.50 & 0.90 & 1.00 & 0.37 & 0.74 \\
\hline Belgium & 1.10 & 1.10 & 0.81 & 0.96 & 1.80 & 3.30 & 1.50 & 2.10 \\
\hline Bolivia & 0.98 & 1.80 & 0.25 & 1.20 & 0.78 & 0.79 & 0.50 & 0.62 \\
\hline Uruguay & 0.94 & 1.10 & 0.59 & 0.84 & 1.50 & 1.50 & 0.56 & 0.95 \\
\hline Peru & 0.90 & 0.90 & 0.38 & 0.61 & 1.10 & 1.20 & 0.50 & 0.89 \\
\hline Paraguay & 0.89 & 0.99 & 0.32 & 0.52 & 1.20 & 1.50 & 0.83 & 1.20 \\
\hline Colombia & 0.66 & 0.75 & 0.19 & 0.47 & 1.20 & 1.60 & 0.95 & 1.20 \\
\hline Portugal & 0.47 & 0.48 & 0.28 & 0.37 & 0.36 & 1.10 & 0.36 & 0.77 \\
\hline Venezuela & 0.30 & 2.40 & 0.29 & 0.66 & 0.70 & 3.00 & 0.70 & 1.90 \\
\hline South Africa & 0.24 & 0.52 & 0.24 & 0.40 & 0.76 & 1.20 & 0.55 & 0.84 \\
\hline Ghana & 0.13 & 0.13 & 0.001 & 0.02 & 0.12 & 0.20 & 0.04 & 0.14 \\
\hline Ecuador & 0.10 & 0.13 & 0.03 & 0.06 & 0.36 & 0.65 & 0.25 & 0.44 \\
\hline Bangladesh & 0.09 & 0.12 & 0.01 & 0.05 & 0.59 & 0.61 & 0.08 & 0.26 \\
\hline Angola & 0.05 & 1.30 & 0.0002 & 0.26 & 0.29 & 1.00 & 0.20 & 0.49 \\
\hline Pakistan & 0.03 & 0.04 & 0.01 & 0.03 & 0.24 & 0.25 & 0.05 & 0.12 \\
\hline Senegal & 0.003 & 0.005 & 0.00003 & 0.002 & 0.05 & 0.11 & 0.02 & 0.07 \\
\hline Haiti & 0.0004 & 0.001 & 0.00002 & 0.0004 & 0.02 & 0.05 & 0.02 & 0.03 \\
\hline
\end{tabular}

Note:\% 2016, $\max \%, \min \%$ and mean $\%$, represents, respectively: the share of trade flows in 2016, the maximum, minimum and average share of trade flows between 2002 and 2016. 
Table A.2: States' participation on Brazilian trade flows

\begin{tabular}{|c|c|c|c|c|c|c|c|c|c|}
\hline & & \multicolumn{4}{|c|}{ Imports } & \multicolumn{4}{|c|}{ Exports } \\
\hline State & Region & $\% 2016$ & $\max \%$ & $\min \%$ & mean \% & $\% 2016$ & $\max \%$ & $\min \%$ & mean $\%$ \\
\hline SP & \multirow{4}{*}{ SE } & 38.00 & 46.00 & 35.00 & 40.00 & 28.00 & 40.00 & 26.00 & 32.00 \\
\hline RJ & & 9.10 & 11.00 & 8.00 & 9.30 & 11.00 & 13.00 & 5.10 & 9.20 \\
\hline $\mathrm{MG}$ & & 4.80 & 6.10 & 4.80 & 5.30 & 11.00 & 15.00 & 9.00 & 11.00 \\
\hline ES & & 2.70 & 5.60 & 2.70 & 4.30 & 3.60 & 6.10 & 3.60 & 5.10 \\
\hline $\mathrm{PR}$ & \multirow{3}{*}{$\mathrm{SU}$} & 8.10 & 8.90 & 6.20 & 7.70 & 8.80 & 9.60 & 7.60 & 8.30 \\
\hline $\mathrm{SC}$ & & 7.50 & 7.50 & 1.60 & 4.60 & 5.20 & 6.10 & 4.20 & 5.10 \\
\hline $\mathrm{RS}$ & & 6.00 & 9.10 & 5.80 & 7.40 & 8.20 & 11.00 & 7.00 & 8.90 \\
\hline GO & \multirow{4}{*}{$\mathrm{CO}$} & 1.90 & 2.50 & 0.69 & 1.50 & 2.50 & 2.50 & 0.59 & 1.50 \\
\hline MS & & 1.70 & 2.40 & 0.30 & 1.70 & 1.60 & 1.70 & 0.33 & 0.88 \\
\hline $\mathrm{DF}$ & & 1.10 & 1.20 & 0.52 & 0.84 & 0.07 & 0.18 & 0.005 & 0.04 \\
\hline MT & & 0.86 & 0.86 & 0.18 & 0.61 & 5.50 & 5.70 & 1.10 & 3.00 \\
\hline $\mathrm{AM}$ & \multirow{7}{*}{ NO } & 4.50 & 7.10 & 4.50 & 6.10 & 0.34 & 1.80 & 0.34 & 0.91 \\
\hline $\mathrm{PA}$ & & 0.81 & 0.81 & 0.43 & 0.56 & 5.60 & 7.10 & 3.60 & 5.10 \\
\hline $\mathrm{RO}$ & & 0.40 & 0.40 & .02 & 0.16 & 0.44 & 0.45 & 0.11 & 0.23 \\
\hline TO & & 0.09 & 0.13 & 0.01 & 0.06 & 0.38 & 0.49 & 0.01 & 0.18 \\
\hline $\mathrm{AP}$ & & 0.01 & 0.05 & 0.01 & 0.03 & 0.14 & 0.24 & 0.03 & 0.11 \\
\hline $\mathrm{RR}$ & & 0.005 & 0.01 & 0.001 & 0.004 & 0.01 & 0.01 & 0.002 & 0.01 \\
\hline $\mathrm{AC}$ & & 0.001 & 0.01 & 0.001 & 0.003 & 0.01 & 0.02 & 0.001 & 0.01 \\
\hline $\mathrm{BA}$ & \multirow{9}{*}{$\mathrm{NE}$} & 4.50 & 4.90 & 3.40 & 4.10 & 3.50 & 5.00 & 3.50 & 4.20 \\
\hline $\mathrm{PE}$ & & 3.20 & 3.20 & 1.10 & 2.00 & 0.81 & 0.82 & 0.35 & 0.55 \\
\hline $\mathrm{CE}$ & & 2.50 & 2.50 & 0.80 & 1.20 & 0.72 & 1.00 & 0.58 & 0.75 \\
\hline MA & & 1.50 & 3.20 & 0.87 & 2.00 & 1.20 & 1.60 & 0.87 & 1.20 \\
\hline $\mathrm{AL}$ & & 0.44 & 0.44 & 0.09 & 0.19 & 0.25 & 0.54 & 0.25 & 0.41 \\
\hline $\mathrm{PB}$ & & 0.23 & 0.43 & 0.13 & 0.25 & 0.07 & 0.23 & 0.07 & 0.13 \\
\hline $\mathrm{RN}$ & & 0.13 & 0.35 & 0.10 & 0.16 & 0.15 & 0.64 & 0.10 & 0.24 \\
\hline $\mathrm{SE}$ & & 0.11 & 0.22 & 0.10 & 0.14 & 0.06 & 0.09 & 0.03 & 0.05 \\
\hline PI & & 0.07 & 0.11 & 0.02 & 0.05 & 0.07 & 0.17 & 0.02 & 0.06 \\
\hline
\end{tabular}

Note: \% 2016, $\max \%, \min \%$ and mean $\%$, represents, respectively: the share of trade flows in 2016,the maximum, minimum and average share of trade flows between 2002 and 2016. $\mathrm{SE}=$ Southeast; $\mathrm{SU}=$ South; $\mathrm{CO}=$ Midwest; $\mathrm{NO}=$ North; $\mathrm{NE}=$ Northeast. 
Table A.3: Nationalities Availability in the Data

\begin{tabular}{|l|c|}
\hline \multicolumn{1}{|c|}{ Countries } & Years \\
\hline ARG; BOL; CHL; PRY; URY; DEU; BEL; UK; & \\
CAN; ESP; USA; FRA; CHE; ITA; JPN; CHN; & $2002-2016$ \\
KOR; PRT & \\
\hline $\begin{array}{l}\text { VEN; COL; PER; ECU; HTI; RUS; PAK; IND; } \\
\text { AGO; ZAF }\end{array}$ & $2011-2016$ \\
\hline SEN; GHA & $2014-2016$ \\
\hline
\end{tabular}

Table A.4: Examples of Product Categories

\begin{tabular}{|l|c|}
\hline \multicolumn{1}{|c|}{ Category } & Number of Products \\
\hline Butter and other fats and oils derived from milk; dairy spreads & 4 \\
\hline Live bovine animals & 16 \\
\hline Polymers of ethylene, in primary forms & 16 \\
\hline Woven fabrics of artificial staple fibres & 20 \\
\hline Electronic integrated circuits and microassemblies & 79 \\
\hline
\end{tabular}


Table A.5: Example of the weighted immigration variables calculation

\begin{tabular}{|c|c|c|c|c|c|c|c|c|c|}
\hline & \multicolumn{6}{|c|}{$\begin{array}{c}\text { Number of total directors and } \\
\text { (number of directors from "k") } \\
\text { in exporting firms that exported "x" } \\
\text { million dollars during } t\end{array}$} & \multicolumn{3}{|c|}{$\begin{array}{c}\text { Variables } \\
* I m m i g r \_D i r e c t o r \_E x p_{i k t}\end{array}$} \\
\hline & $\begin{array}{c}\mathrm{x}<1 \\
\mathrm{P}=1 \\
\mathrm{P} 2=0.5\end{array}$ & $\begin{array}{c}1<\mathrm{x}<5 \\
\mathrm{P}=2 \\
\mathrm{P} 2=2.5\end{array}$ & $\begin{array}{c}5<\mathrm{x}<10 \\
\mathrm{P}=3 \\
\mathrm{P} 2=7.5\end{array}$ & $\begin{array}{c}10<\mathrm{x}<50 \\
\mathrm{P}=4 \\
\mathrm{P} 2=30\end{array}$ & $\begin{array}{c}50<\mathrm{x}<100 \\
\mathrm{P}=5 \\
\mathrm{P} 2=75\end{array}$ & $\begin{array}{c}x>100 \\
P=6 \\
P 2=100\end{array}$ & No weight & $*=\mathrm{P}$ & $*=\mathrm{P} 2$ \\
\hline $\begin{array}{c}\text { Municipality } \\
1 \\
\end{array}$ & $\begin{array}{c}50 \\
(10) \\
\end{array}$ & $\begin{array}{c}50 \\
(20) \\
\end{array}$ & & & & & $\begin{array}{c}(10+20) /(50+50) \\
=0.30\end{array}$ & $\begin{array}{c}(10+40) /(50+100) \\
=0.333\end{array}$ & $\begin{array}{c}(5+50) /(25+125) \\
=0.367\end{array}$ \\
\hline $\begin{array}{c}\text { Municipality } \\
2\end{array}$ & $\begin{array}{c}50 \\
(10)\end{array}$ & & & $\begin{array}{l}50 \\
(20)\end{array}$ & & & $\begin{array}{c}(10+20) /(50+50) \\
=0.30\end{array}$ & $\begin{array}{c}(10+80) /(50+200) \\
=0.360\end{array}$ & $\begin{array}{c}(5+600) /(25+1500) \\
=0.397\end{array}$ \\
\hline $\begin{array}{c}\text { Municipality } \\
3\end{array}$ & $\begin{array}{c}50 \\
(10)\end{array}$ & & & & & $\begin{array}{c}50 \\
(20)\end{array}$ & $\begin{array}{c}(10+20) /(50+50) \\
=0.30\end{array}$ & $\begin{array}{c}(10+120) /(50+300) \\
=0.371\end{array}$ & $\begin{array}{c}(5+2000) /(25+5000) \\
=0.399\end{array}$ \\
\hline
\end{tabular}


Table A.6: Effect of Immigrants on Exports and Imports (Diminishing Marginal Effects)

\begin{tabular}{|c|c|c|c|c|c|c|}
\hline Variables & $\begin{array}{c}(\text { OLS }) \\
\text { I }(\text { Export }>0)\end{array}$ & $\begin{array}{l}\text { (PPML) } \\
\text { Export }\end{array}$ & $\begin{array}{c}(\text { OLS }) \\
\ln (\text { Export }+1)\end{array}$ & $\begin{array}{c}(\text { OLS }) \\
\text { I }(\text { Import }>0)\end{array}$ & $\begin{array}{l}\text { (PPML) } \\
\text { Import }\end{array}$ & $\begin{array}{c}\text { (OLS) } \\
\ln (\text { Import }+1)\end{array}$ \\
\hline Immigr_Director_Exp & $\begin{array}{c}1.329^{* * *} \\
(0.171)\end{array}$ & $\begin{array}{c}19.485^{* * *} \\
(4.105)\end{array}$ & $\begin{array}{c}21.613^{* * *} \\
(2.550)\end{array}$ & & & \\
\hline Immigr_Director_Exp ${ }^{2}$ & $\begin{array}{c}-1.148^{* * *} \\
(0.204)\end{array}$ & $\begin{array}{c}-68.484^{* *} \\
(31.469)\end{array}$ & $\begin{array}{c}-20.481^{* * *} \\
(2.929)\end{array}$ & & & \\
\hline Immigr_NonDirector_Exp & $\begin{array}{c}0.151 \\
(0.338)\end{array}$ & $\begin{array}{l}-6.153 \\
(7.121)\end{array}$ & $\begin{array}{l}-3.677 \\
(5.190)\end{array}$ & & & \\
\hline Immigr_Director_Imp & & & & $\begin{array}{c}1.675^{* * *} \\
(0.158)\end{array}$ & $\begin{array}{c}23.14^{* * *} \\
(5.93)\end{array}$ & $\begin{array}{c}30.574^{* * *} \\
(2.321)\end{array}$ \\
\hline Immigr_Director_Imp $p^{2}$ & & & & $\begin{array}{c}-1.563^{* * *} \\
(0.182)\end{array}$ & $\begin{array}{l}-49.22 \\
(30.87)\end{array}$ & $\begin{array}{c}-30.176^{* * *} \\
(2.653)\end{array}$ \\
\hline Immigr_NonDirector_Imp & & & & $\begin{array}{c}0.201 \\
(0.319)\end{array}$ & $\begin{array}{l}-10.49 \\
(12.17)\end{array}$ & $\begin{array}{c}6.291 \\
(4.798)\end{array}$ \\
\hline Immigr & $\begin{array}{c}5.420^{* * *} \\
(1.717)\end{array}$ & $\begin{array}{c}156.963^{* * *} \\
(23.627)\end{array}$ & $\begin{array}{c}102.977^{* * *} \\
(27.690)\end{array}$ & $\begin{array}{c}2.325^{* *} \\
(0.998)\end{array}$ & $\begin{array}{c}130.15^{* * *} \\
(35.52)\end{array}$ & $\begin{array}{c}33.967 \\
(20.775)\end{array}$ \\
\hline $\ln \left(\mathrm{GDP} \_\right.$Masses $)$ & $\begin{array}{c}0.093^{* * *} \\
(0.004)\end{array}$ & $\begin{array}{c}1.204^{* * *} \\
(0.071)\end{array}$ & $\begin{array}{c}1.531^{* * *} \\
(0.055)\end{array}$ & $\begin{array}{c}0.098 * * * \\
(0.004)\end{array}$ & $\begin{array}{c}0.97^{* * *} \\
(0.08)\end{array}$ & $\begin{array}{c}1.497^{* * * *} \\
(0.051)\end{array}$ \\
\hline $\ln ($ DISTANCE) & $\begin{array}{c}-0.066^{* *} \\
(0.028)\end{array}$ & $\begin{array}{l}-0.161 \\
(0.711)\end{array}$ & $\begin{array}{l}-0.362 \\
(0.375)\end{array}$ & $\begin{array}{c}-0.461^{* * *} \\
(0.028)\end{array}$ & $\begin{array}{c}-4.74^{* * *} \\
(0.59)\end{array}$ & $\begin{array}{c}-6.674^{* * *} \\
(0.398)\end{array}$ \\
\hline Observations & 473,427 & 465,781 & 473,427 & 440,555 & 430,361 & 440,555 \\
\hline Municipalities & 2,293 & 2,150 & 2,293 & 2,217 & 2,102 & 2,217 \\
\hline R-squared & 0.433 & 0.769 & 0.488 & 0.486 & 0.8650 & 0.564 \\
\hline Ramsey Test & & 0.3133 & 0.000 & & 0.0548 & 0.0149 \\
\hline Municipality FE & YES & YES & YES & YES & YES & YES \\
\hline State-Year FE & YES & YES & YES & YES & YES & YES \\
\hline State-Country FE & YES & YES & YES & YES & YES & YES \\
\hline
\end{tabular}

Notes: (Table A.6) ${ }^{*}=$ Statistically significant at the 10 percent level. ${ }^{* *}=$ Statistically significant at the 5 percent level. ${ }^{* * *}=$ Statistically significant at the 1 percent level. Robust standard errors clustered by the pair municipality-country in parentheses. OLS $=$ Ordinary Least Squares. PPML = Pseudo Poisson Maximum Likelihood. The R-squared for equations estimated with PPML is the Pseudo-R-squared. The Ramsey test is calculated accordingly to Silva and Tenreyro (2006). Dependent variables are a dummy indicating if municipality "i" exported to "k" during "t" $(I($ Export $>0))$, the value exported (Export), the logarithm of the value exported plus $1(\ln ($ Export +1$))$, a dummy indicating if municipality " $\mathrm{i} "$ imported to "k" during "t" (I(Import $>0))$, the value imported (Import) and the logarithm of the value imported plus $1(\ln ($ Import +1$))$. Immigr is the share of workers of " $\mathrm{i} "$ that are immigrants from "k", Immigr_Director_Exp (Immigr_Director_Imp) is the share of management positions in exporting (importing) firms of "i" occupied by immigrants from "k". Immigr_NonDirector_Exp(Immigr_NonDirector_Imp) is the share of nonmanagement positions in exporting (importing) firms of "i" occupied by immigrants from "k". 
Table A.7: Effect of Immigrants on Exports and Imports (Lags)

\begin{tabular}{|c|c|c|c|c|c|}
\hline Lags: & $\begin{array}{l}(\mathrm{OLS}) \\
(\mathrm{j}=1)\end{array}$ & $\begin{array}{l}(\mathrm{OLS}) \\
(\mathrm{j}=2)\end{array}$ & $\begin{array}{l}(\mathrm{OLS}) \\
(\mathrm{j}=3)\end{array}$ & $\begin{array}{c}\text { (PPML) } \\
(\mathrm{j}=2)\end{array}$ & $\begin{array}{c}(\text { PPML }) \\
(j=3)\end{array}$ \\
\hline Panel A. & $\mathrm{I}($ Export $>0)$ & $\mathrm{I}($ Export $>0)$ & $\mathrm{I}($ Export $>0)$ & Export & Export \\
\hline Immigr_Director_Expt-j & $\begin{array}{c}0.369^{* * *} \\
(0.087)\end{array}$ & $\begin{array}{c}0.308^{* * *} \\
(0.087)\end{array}$ & $\begin{array}{c}0.326^{* * *} \\
(0.088)\end{array}$ & $\begin{array}{c}3.61^{* * *} \\
(0.64)\end{array}$ & $\begin{array}{c}3.44^{* * *} \\
(0.67)\end{array}$ \\
\hline Immigr_NonDirector_Expt $p_{t-j}$ & $\begin{array}{l}-0.238 \\
(0.384)\end{array}$ & $\begin{array}{l}-0.528 \\
(0.450)\end{array}$ & $\begin{array}{l}-1.016^{*} \\
(0.553)\end{array}$ & $\begin{array}{c}0.70 \\
(4.45)\end{array}$ & $\begin{array}{c}1.85 \\
(22.09)\end{array}$ \\
\hline Immigr $_{t-j}$ & $\begin{array}{c}6.026^{* * *} \\
6.026^{* * *} \\
(1.911)\end{array}$ & $\begin{array}{c}6.871^{* * *} \\
7.630^{* * *} \\
(2.380)\end{array}$ & $\begin{array}{c}5.663^{* * *} \\
6.340^{* * *} \\
(1.449)\end{array}$ & $\begin{array}{c}124.99^{* * *} \\
234.24^{* * *} \\
(36.94)\end{array}$ & $\begin{array}{c}112.67^{* * *} \\
283.63^{* * *} \\
(59.37)\end{array}$ \\
\hline $\ln \left(\mathrm{GDP} \_\right.$Masses $)$ & $\begin{array}{c}0.091^{* * *} \\
(0.004)\end{array}$ & $\begin{array}{c}0.090 * * * \\
(0.004)\end{array}$ & $\begin{array}{c}0.093^{* * *} \\
(0.005)\end{array}$ & $\begin{array}{c}1.17^{* * *} \\
(0.08)\end{array}$ & $\begin{array}{c}1.13^{* * *} \\
(0.08)\end{array}$ \\
\hline $\ln ($ DISTANCE) & $\begin{array}{c}-0.063^{* *} \\
(0.028)\end{array}$ & $\begin{array}{c}-0.062^{* *} \\
(0.029)\end{array}$ & $\begin{array}{c}-0.057^{* *} \\
(0.029)\end{array}$ & $\begin{array}{l}-0.10 \\
(0.74)\end{array}$ & $\begin{array}{l}-0.22 \\
(0.72)\end{array}$ \\
\hline Observations & 425,792 & 398,802 & 371,723 & 385,332 & 354,974 \\
\hline Municipalities & 2,241 & 2,277 & 2,269 & 1,913 & 1,832 \\
\hline R-squared & 0.440 & 0.447 & 0.453 & 0.7673 & 0.7663 \\
\hline
\end{tabular}

\begin{tabular}{|c|c|c|c|c|c|}
\hline Panel B. & $\mathrm{I}($ Import $>0)$ & $\mathrm{I}($ Import $>0)$ & $\mathrm{I}($ Import $>0)$ & Import & Import \\
\hline \multirow[t]{2}{*}{ Immigr_Director_Imp $p_{t-j}$} & $0.475^{* * *}$ & $0.467^{* * *}$ & $0.359^{* * *}$ & $7.05^{* * *}$ & $6.59^{* * *}$ \\
\hline & $(0.090)$ & $(0.089)$ & $(0.081)$ & $(1.18)$ & $(1.22)$ \\
\hline \multirow[t]{2}{*}{ Immigr_NonDirector_Imp $p_{t-j}$} & 0.021 & 0.150 & 0.029 & -5.24 & 31.93 \\
\hline & $(0.313)$ & $(0.291)$ & $(0.273)$ & $(12.20)$ & $(21.98)$ \\
\hline \multirow[t]{2}{*}{ Immigr $_{t-j}$} & $3.558^{* *}$ & $2.731^{* * *}$ & $3.234^{* * *}$ & $122.41^{* *}$ & 78.75 \\
\hline & $(1.531)$ & $(1.041)$ & $(1.119)$ & $(51.88)$ & $(83.83)$ \\
\hline \multirow[t]{2}{*}{$\ln \left(\mathrm{GDP} \_\right.$Masses $)$} & $0.094^{* * *}$ & $0.090^{* * *}$ & $0.080^{* * *}$ & $0.90 * * *$ & $0.84^{* * *}$ \\
\hline & $(0.004)$ & $(0.004)$ & $(0.004)$ & $(0.08)$ & $(0.08)$ \\
\hline \multirow[t]{2}{*}{$\ln (\mathrm{DISTANCE})$} & $-0.449 * * *$ & $-0.444^{* * *}$ & $-0.431^{* * *}$ & $-4.93^{* * *}$ & $-5.03 * * *$ \\
\hline & $(0.029)$ & $(0.029)$ & $(0.030)$ & $(0.60)$ & $(0.60)$ \\
\hline Observations & 396,566 & 369,633 & 342,529 & 350,468 & 322,384 \\
\hline Municipalities & 2,166 & 2,189 & 2,180 & 1,772 & 1,723 \\
\hline R-squared & 0.495 & 0.501 & 0.507 & 0.8642 & 0.8645 \\
\hline Municipality FE & YES & YES & YES & YES & YES \\
\hline State-Year FE & YES & YES & YES & YES & YES \\
\hline State-Country FE & YES & YES & YES & YES & YES \\
\hline
\end{tabular}

Notes: (Table A.7) $*=$ Statistically significant at the 10 percent level. ${ }^{* *}=$ Statistically significant at the 5 percent level. ${ }^{* *}=$ Statistically significant at the 1 percent level. Robust standard errors clustered by the pair municipality-country in parentheses. OLS= Ordinary Least Squares. PPML = Pseudo Poisson Maximum Likelihood. The R-squared for equations estimated with PPML is the Pseudo-R-squared. "j" defines the lag used ("t-1", "t-2" or "t$3^{\prime \prime)}$. $(I($ Export $>0))$ is a dummy indicating if municipality "i" exported to "k" during "t", (Export) is the value exported, (I(Import $>0))$ is a dummy indicating if municipality " $\mathrm{i} "$ imported to "k" during "t" and (Import) is the value imported. Immigr is the share of workers of "i" that are immigrants from "k", Immigr_Director_Exp(Immigr_Director_Imp) is the share of management positions in exporting (importing) firms of " $i$ " occupied by immigrants from "k". Immigr_NonDirector_Exp(Immigr_NonDirector_Imp) is the share of non-management positions in exporting (importing) firms of "i" occupied by immigrants from "k". 
Figure A.1: Uruguayan immigrants' distribution in 2016

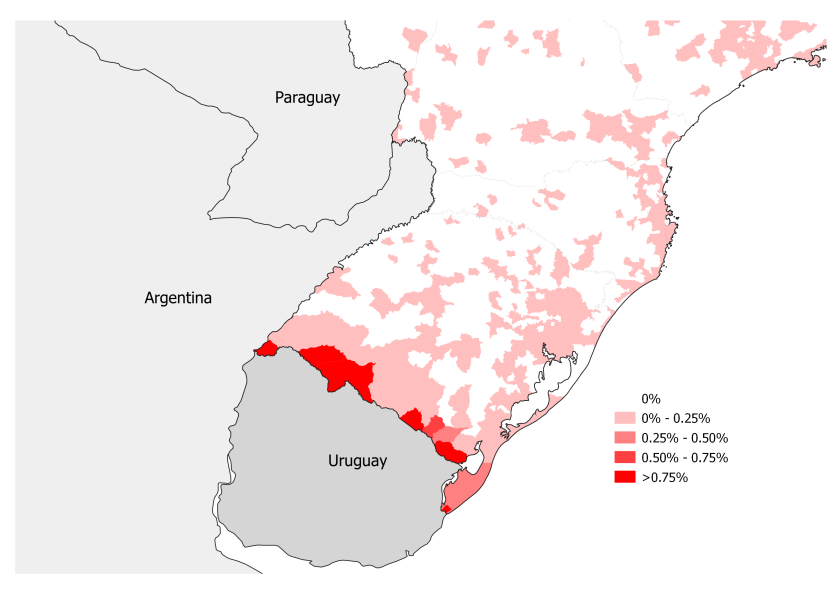

Immigr

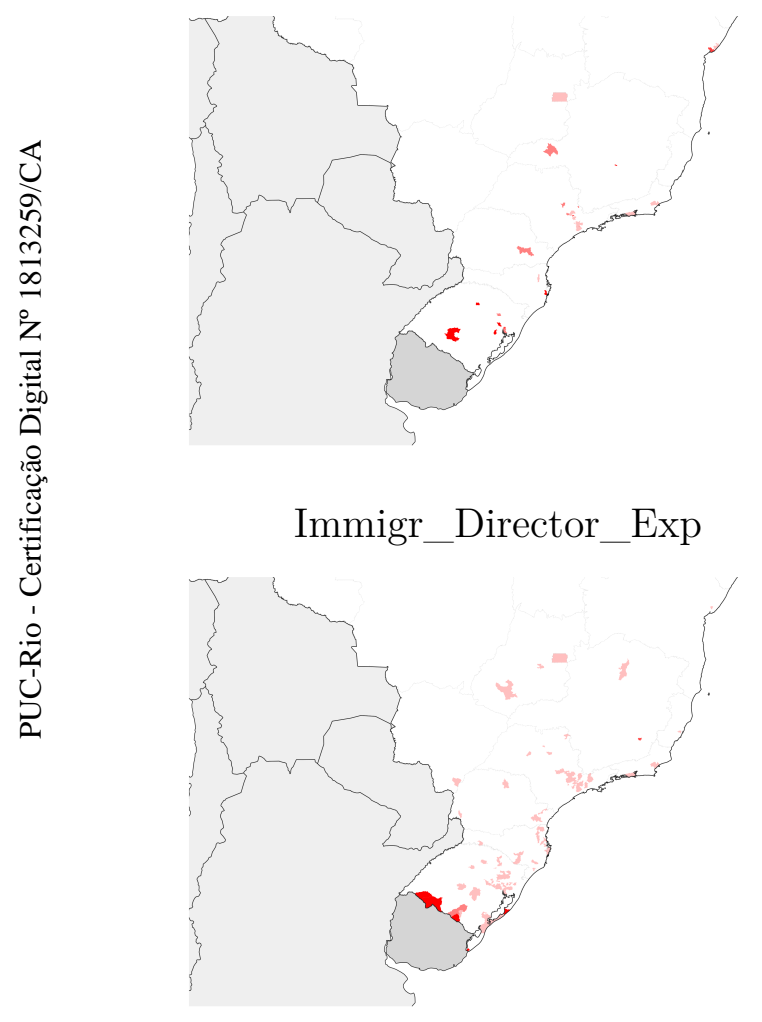

Immigr_NonDirector_Exp

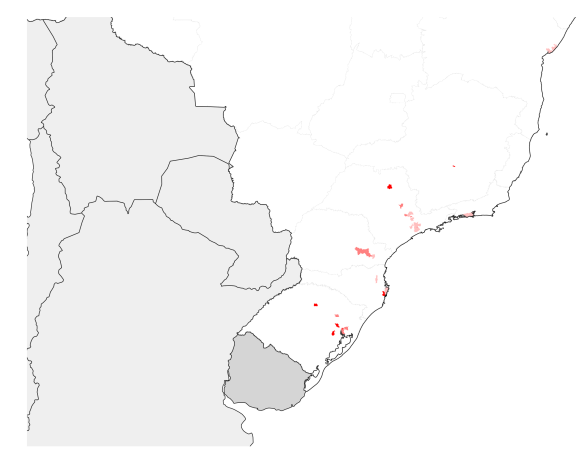

Immigr_Director_Imp

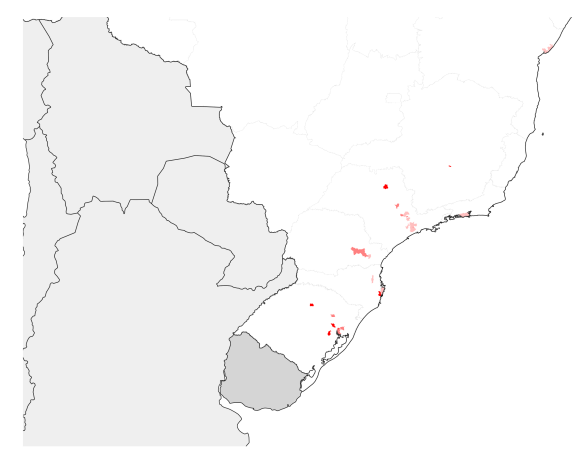

Immigr_NonDirector_Imp 
Figure A.2: Argentine immigrants' distribution in 2016

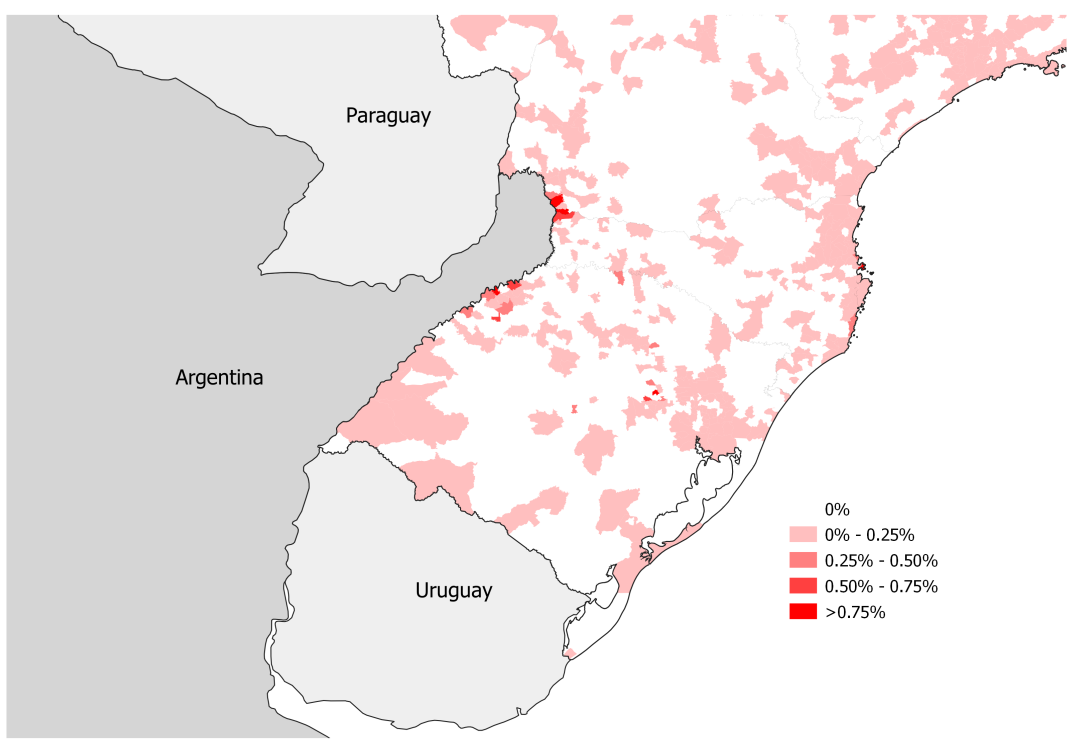

Immigr

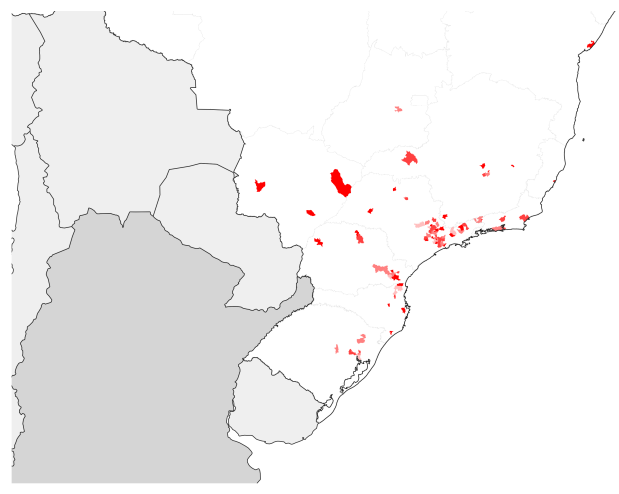

Immigr_Director_Exp

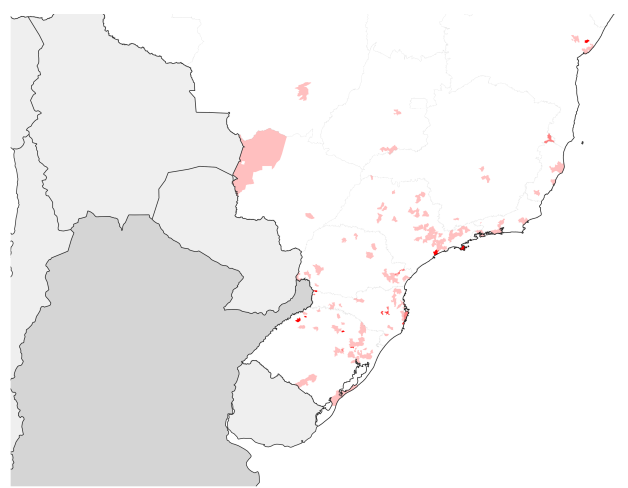

Immigr_NonDirector_Exp

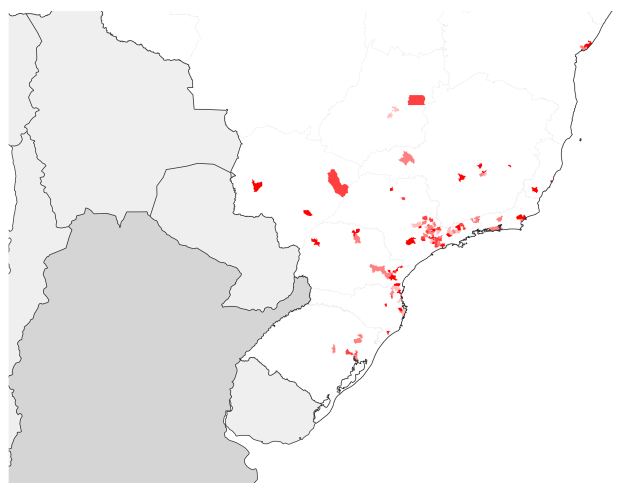

Immigr_Director_Imp

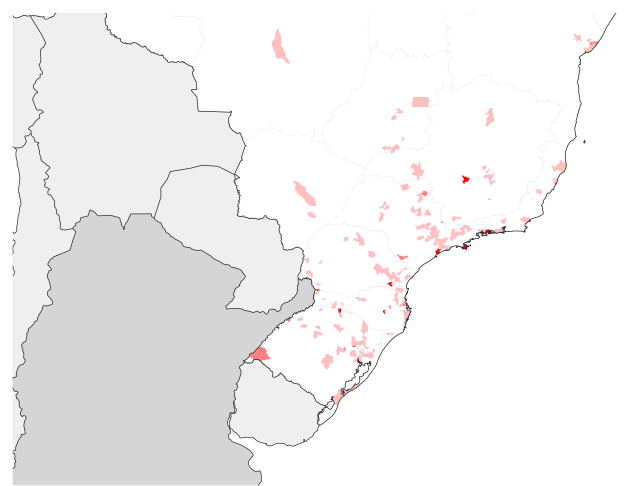

Immigr_NonDirector_Imp 
Figure A.3: Bolivian immigrants' distribution in 2016

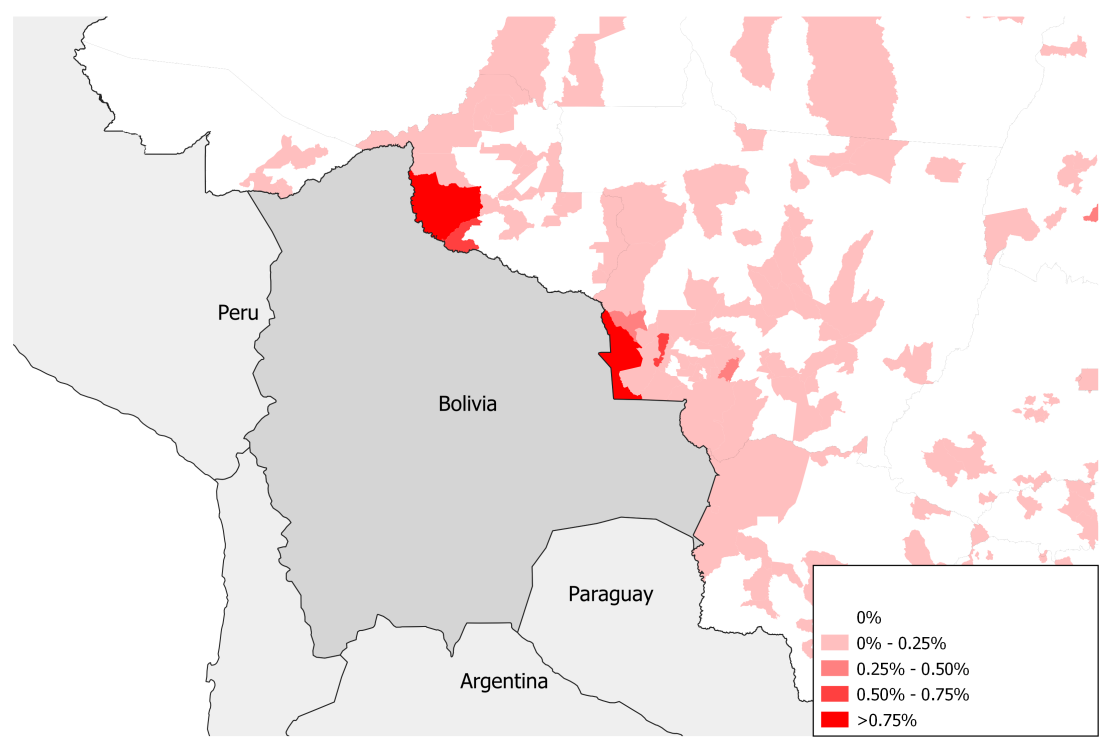

Immigr

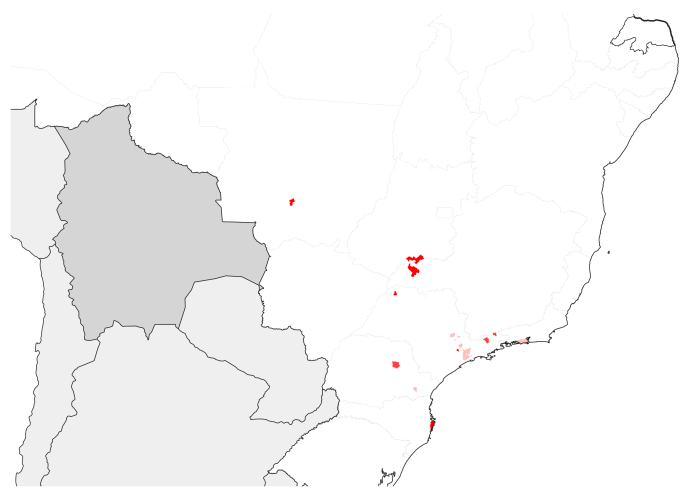

Immigr_Director_Exp

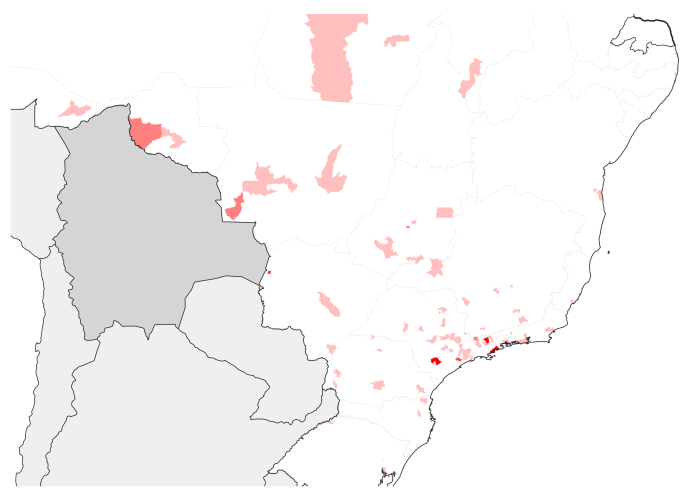

Immigr_NonDirector_Exp

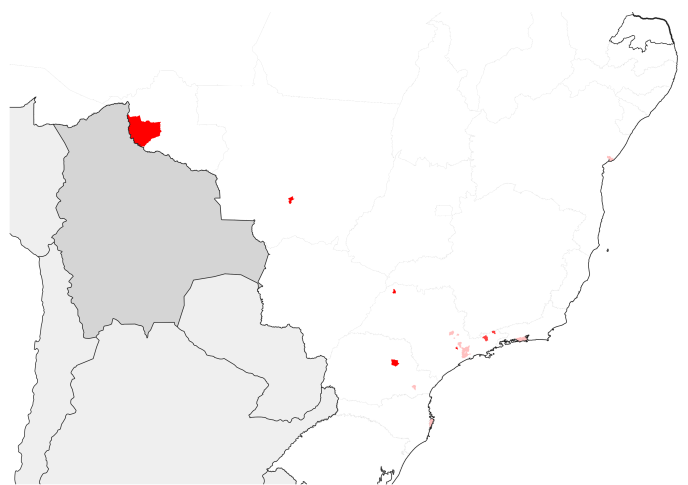

Immigr_Director_Imp

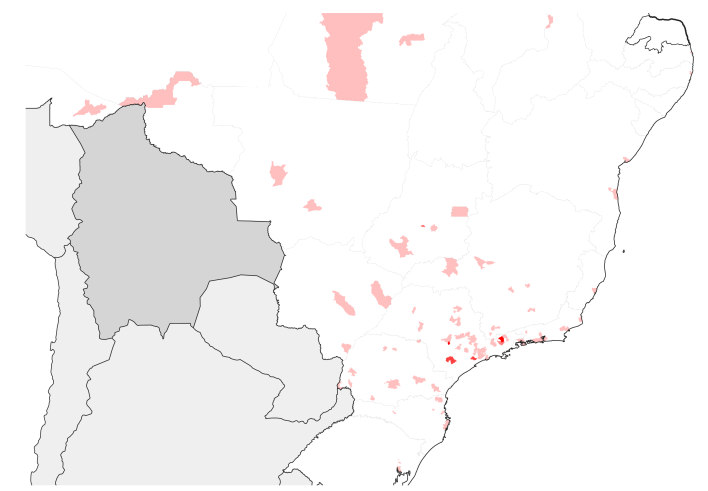

Immigr_NonDirector_Imp 
Figure A.4: Peruvian immigrants' distribution in 2016

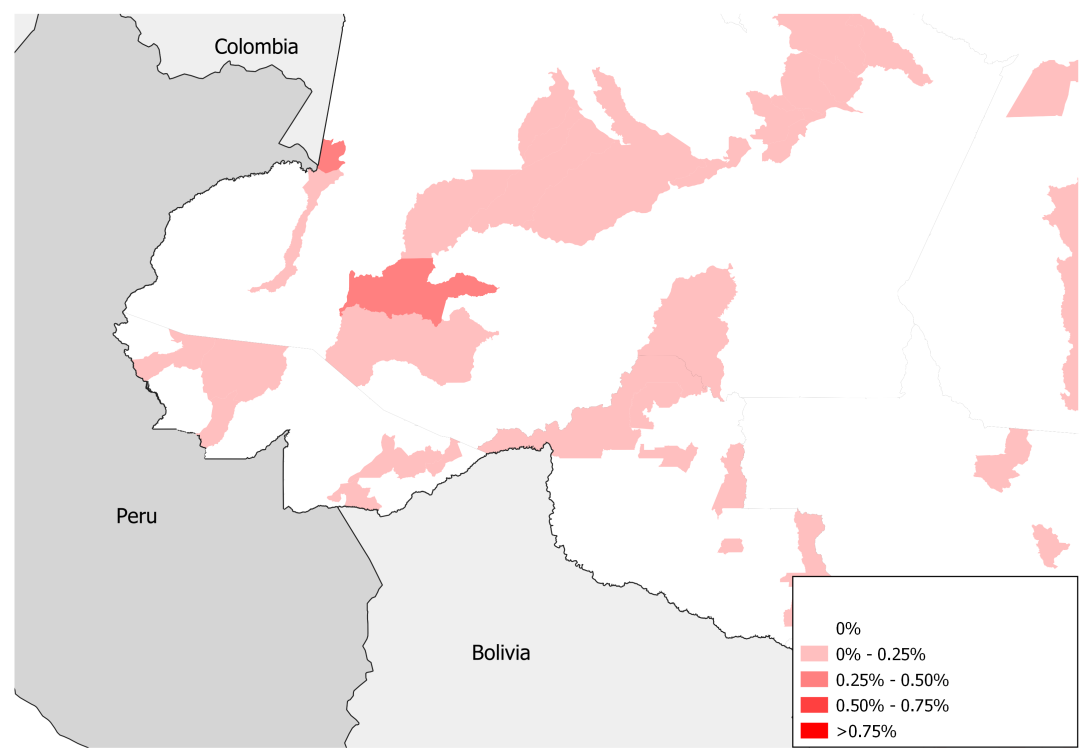

Immigr

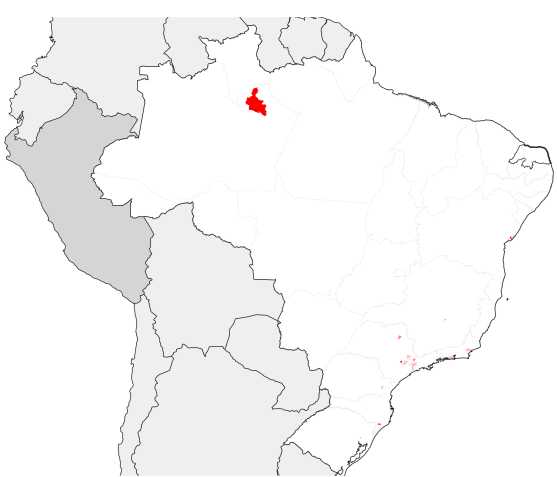

Immigr_Director_Exp

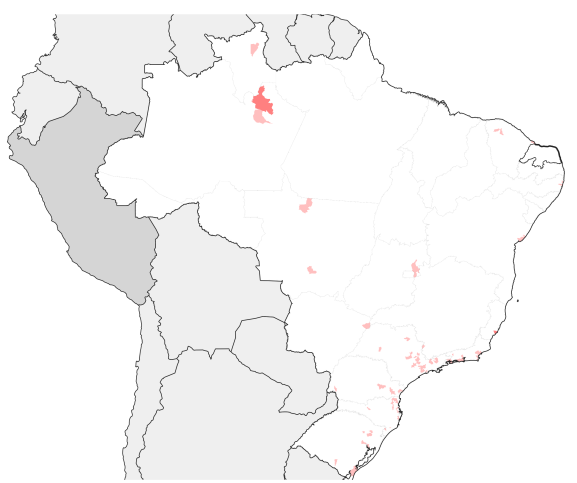

Immigr_NonDirector_Exp

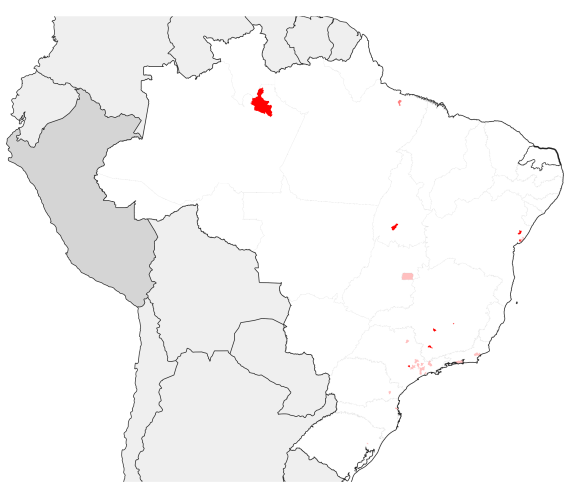

Immigr_Director_Imp

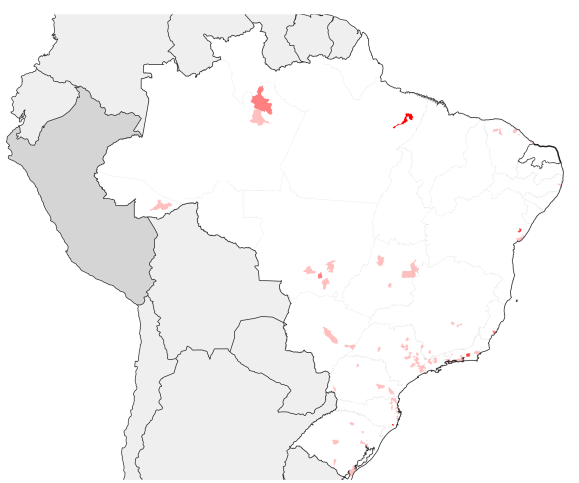

Immigr_NonDirector_Imp 
Figure A.5: Colombian immigrants' distribution in 2016

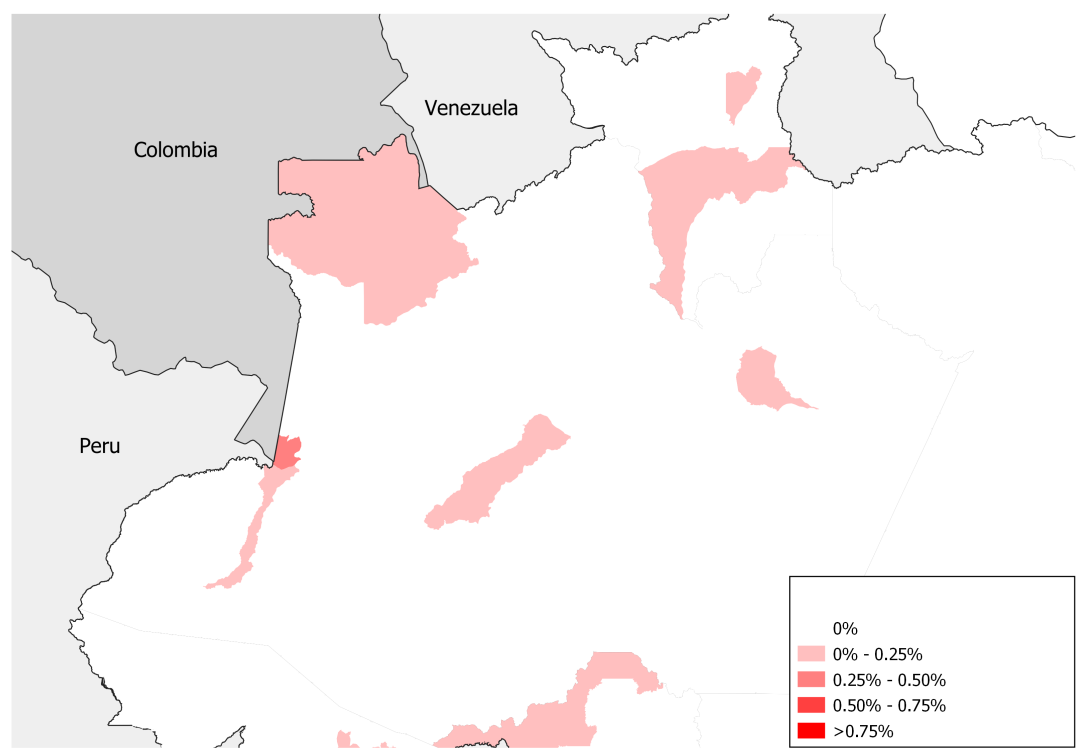

Immigr

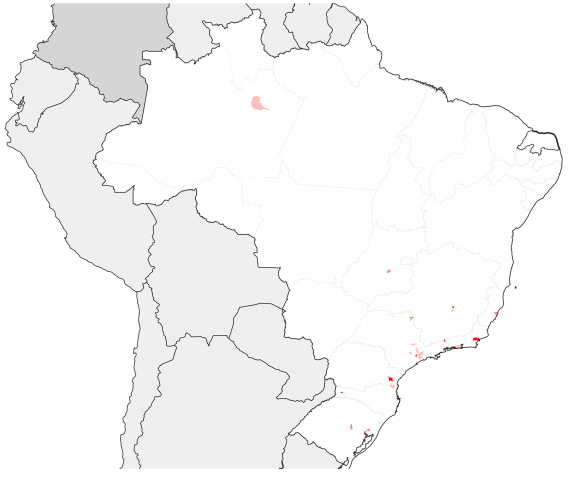

Immigr_Director_Exp

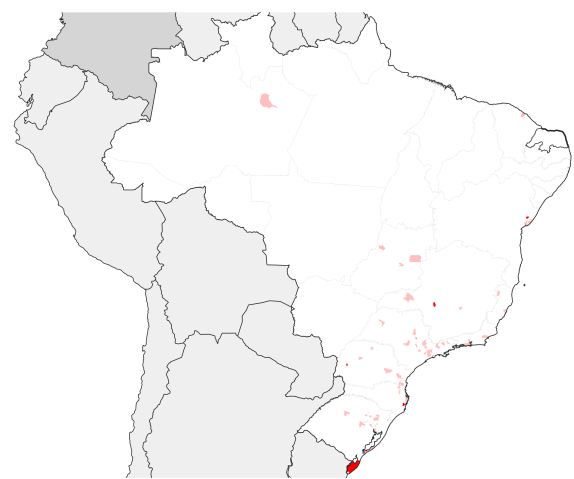

Immigr_NonDirector_Exp

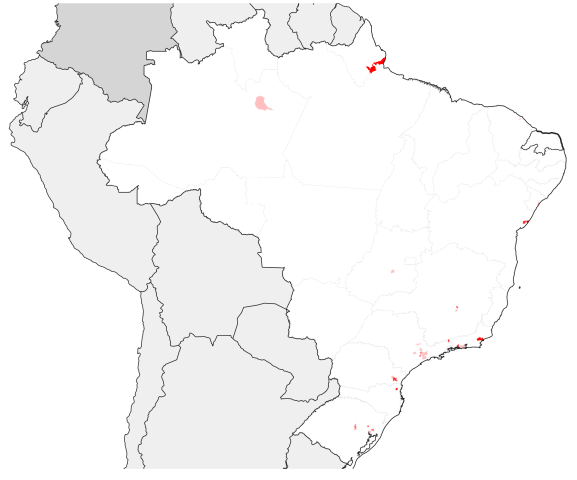

Immigr_Director_Imp

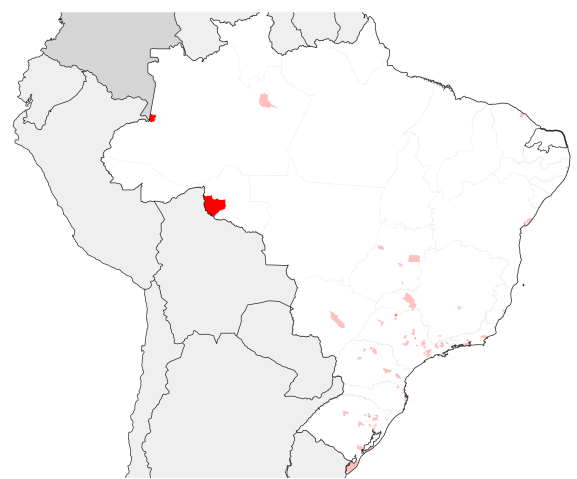

Immigr_NonDirector_Imp 
Figure A.6: Venezuelan immigrants' distribution in 2016

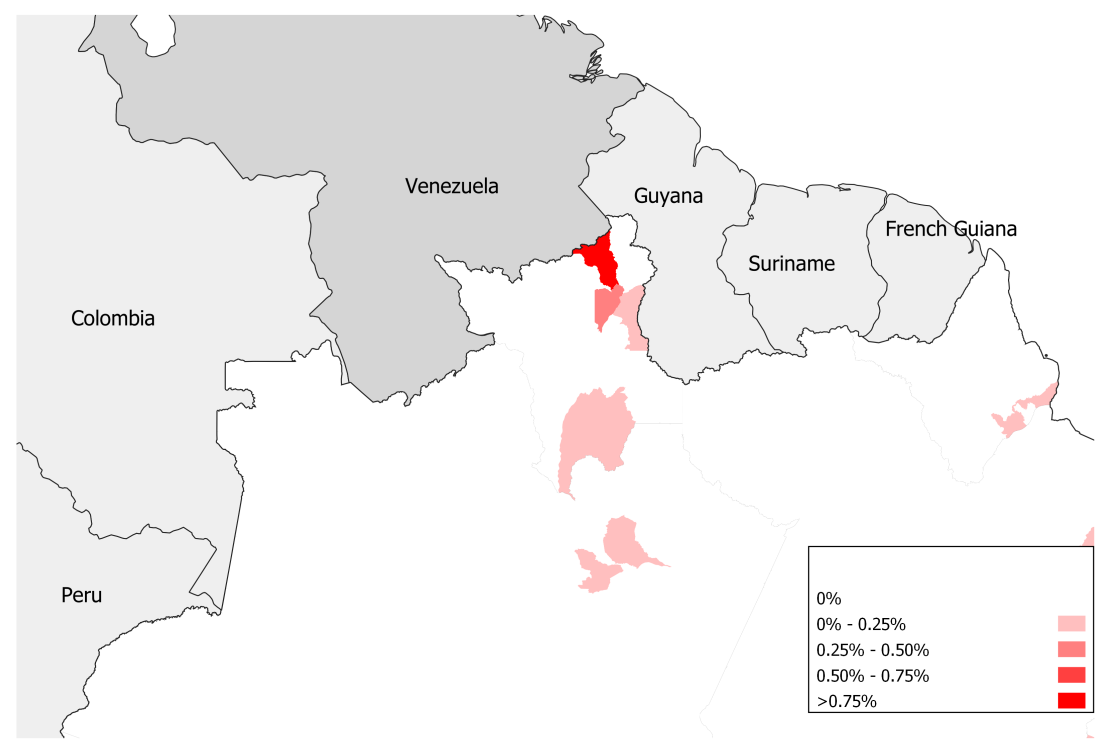

Immigr

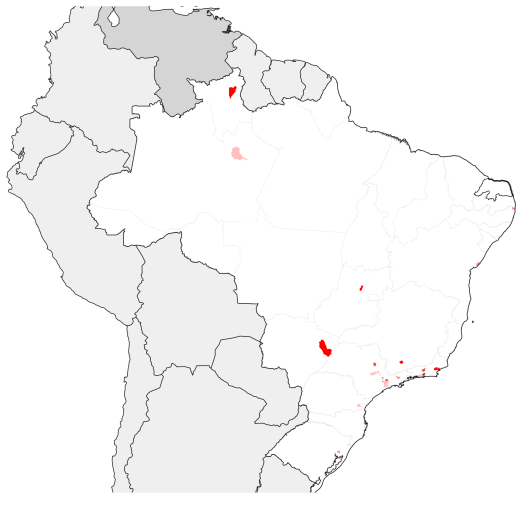

Immigr_Director_Exp

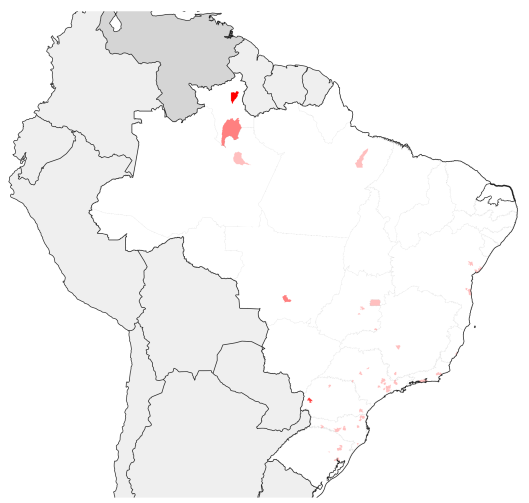

Immigr_NonDirector_Exp

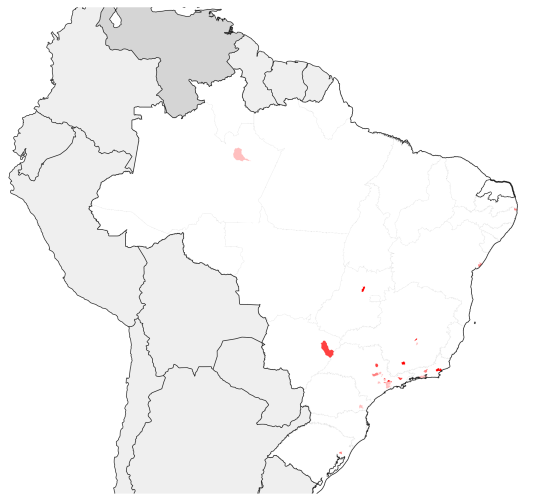

Immigr_Director_Imp

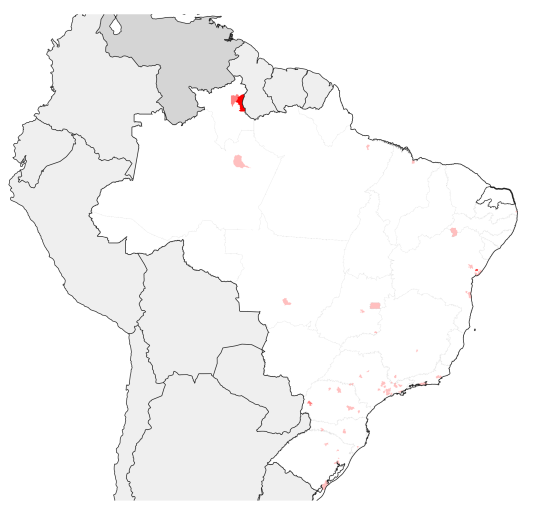

Immigr_NonDirector_Imp 